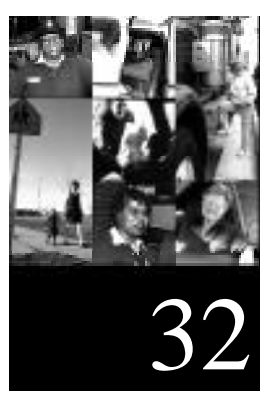

Women in Transit: Findings from African-Americans, Other Minorities, and Women in the Transit Industry

Beverly G. Ward Eric T. Hill CUTR, University of South Florida 



\title{
WOMEN IN TRANSIT: FINDINGS FROM AFRICAN-AMERICANS, OTHER MINORITIES, AND WOMEN IN THE TRANSIT INDUSTRY
}

\begin{abstract}
This research builds on the doctoral dissertation of Philip W. Jeffress, The Negro [sic] in the Urban Transit Industry. Dr. Jeffress explored the degree to which transit may be an industry in which blacks could expect favorable hiring and promotional practices. Jeffress's research took place in the late 1960s, a few years after the enactment of the Civil Rights and Federal Transit Acts. In his final chapter, he posits that the transit industry will continue to provide employment and advancement opportunities for blacks.
\end{abstract}

As a project of the National Urban Transit Institute, the Center for Urban Transportation Research revisited Jeffress's work and expanded the scope of research to include women and all minority groups recognized as protected classes in federal legislation. The research attempts to measure the degree to which minorities and women have realized favorable employment and advancement opportunities in the transit industry.

Data sources include EEO-1 and EEO-4 reports from the transit systems included in Jeffress's original study, a mail survey, and formal telephone and in-person interviews. The EEO reports were used to provide the historical experience of the systems and to measure the labor supply and demand. The mail survey, based on the American Planning Association's 1991 Planners Salary Survey, was used not only to measure salaries, but also to explore perceptions of social equity. The interviews provide additional ethnographic data. The data reveals that the women have made significant gains in the transit industry. Women were previously concentrated in clerical and secretarial positions. The data do suggest, however, that women in management positions are channeled toward human resources or "social service" line positions. The implications of these findings are twofold. First, for the women in these positions, the employment and advancement patterns carry economic and social effects that affect their lives and communities. Second, on a broader level, these employment and advancement practices may not place women in decision making positions within transit agencies. Representation at the decision making levels is important in that women and minorities have the potential to contribute to the quality of service by bringing their perspectives as members of these groups. Failure to include women and minorities in the decision making process ultimately affects the delivery of services perpetuating conditions of economic and social isolation.

This research is exploratory. Additional research is needed among all Section 9, 16 (b) (2), and 18 transit recipients. Similar investigation also could be conducted among Health and Human Service transportation providers. In this era of budget cuts, it is important that funding is expended in the most productive manner. An engendered transit decision making process is essential to this goal. 


\section{INTRODUCTION}

The Negro in the Urban Transit Industry was published in 1970 as part of a research effort to learn why some industries seemed more hospitable to African-American employment, why some companies within those industries seemed to have employment policies that encouraged racial diversity, and to propose "appropriate policy." It was felt that this was a significant area of study for several reasons. Transit served as a source of employment in many areas. In addition, African-Americans are generally the largest consumers of its services. During the decade of 1960 to 1970, transit employment declined. Despite this last factor, the author speculated that labor demand, industrial (and population) location and managerial, union, and government policies would converge to create ". . . a black-operated industry serving a predominant black clientele except where it brings suburban commuters back and forth to center city." 2

In the intervening decades since Dr. Philip W. Jeffress made these speculations, these factors and others have influenced transit employment and service delivery. Examples of the changes in the transit industry:

- The transit labor demand has grown almost $100 \% .^{3}$

- During the decade of the 1980s, the federal government sought to promote increased involvement of the private sector in the provision of public transit services. In 1984, the Federal Transit Administration (FTA) issued a "Policy on Private Participation in the Federal Transit Program." The goal of this policy was to increase efficiencies and reduce cost in public transit.

- Changes in land use patterns, population, and the number of women in the job force have contributed to an unprecedented transportation demand.

- More transit use is being promoted to comply with Clean Air Act Amendments and to provide more efficient energy use.

- The Intermodal Surface Transportation Efficiency Act of 1991 was estimated to create four million jobs between 1991 and 1996. The Act also was touted to offer the opportunity for more citizen participation.

These factors may have had an adverse impact on African-Americans and other minorities with transit employment and service. For example, those changes in land use patterns categorized as suburban sprawl may have made it more difficult for transit to serve outlying areas. Suburban commuters do not just commute "back and forth to center city." Usually, the commute is from one suburban residential area to another suburban business district. This may have caused employment opportunities to become further dispersed and transit service less accessible to existing and potential users, creating declines in transit employment and use. This may be critical for women and minorities. Transit is still a vital source of employment for minorities and women and these groups represent most of transit's ridership. In addition, other issues such as the backlash against affirmative action, transit operating cuts, and technology changes may have negatively influenced employment for minorities and women in this industry.

This research reexamines the role of transit as it relates to African-Americans, other minorities, and women since the research undertaken by Dr. Philip W. Jeffress in 1970. The role of transit as employer and service provider is juxtaposed to the changes in society and the transit industry. While Jeffress's research covered African-American ${ }^{4}$ employment in the transit industry roughly from the 1850s up to 1970, this study will review the changes since 1970 and provide some understanding of their impacts on minorities and women in transit. The research was funded and completed as part of the National Urban Transit Institute at CUTR. 
The paper is presented in five sections. The first section begins with a review of Dr. Jeffress's concluding comments from the Negro in the Urban Transit Industry, and his expectations of the future regarding African-American employment in transit. In addition, an interview was held with Jeffress about the original research and current observations about the industry.

The second section contains information on transit service and employment in this industry, from 1970 through 1990. This includes an analysis of census data and statistics from Equal Employment Opportunity reports. An interpretation of this data in relation to employment changes for minorities and women in transit is provided were appropriate. This information is supplemented by an analysis of data from selected transit systems and a survey of minorities and women in transit.

The third section includes a discussion of the changes that have occurred in transit since Jeffress's study. Changes in the demand and supply of transit resources and use of transit are discussed. Such factors as a changing workforce and socioeconomic condition in American are examined as to their impacts on the transit industry.

Several transportation policies have been established since 1970 which may have influenced the progress of minority and women employees in the transit industry. These policies are discussed in the fourth section and include: the Federal Transit Administration's (FTA) Policy on Private Participation; Title VII of the Civil Rights Act of 1964, as amended; the Clean Air Act Amendments, and the Intermodal Surface Transportation Efficiency Act of 1991. Additionally, significant legal decisions that may have affected affirmative action efforts in transit are reviewed in this section.

Finally, conclusions from this research are presented in the last section. This section sets policy determinants for the next 25 years in the transit industry and amends The Negro in the Urban Transit Industry from 1970 to 1990 .

\section{REVIEW OF THE NEGRO IN THE URBAN TRANSIT INDUSTRY, EXPECTATIONS OF THE FUTURE}

Perhaps a logical departure for this research is to recapture Dr. Jeffress's expectations of the future for African-Americans and the transit industry. In the final chapter of the Negro in the Urban Transit Industry, Dr. Jeffress gives a review of the many influences that resulted in changing policies toward African-Americans in transit.

From 1945 to 1970 African-Americans played an important role in transit, moving first into unskilled and semiskilled jobs and making progress toward an increasing share of skilled and white collar transit positions. Several factors combined to make this happen, including labor demand and industrial location, management policy, union policy, and government policy. Dr. Jeffress anticipated that transit would become evermore influenced by government policies and controlled by African-Americans. This chapter includes an interview with Jeffress about his original research and current observations about the industry.

\section{LABOR DEMAND}

The presence of African-Americans in transit started during the labor shortages of World War II. In subsequent years, the demand for transit labor declined but continued to increase for African-Americans. The author notes that this was "... an almost unique situation that can be understood only by examining 
such factors as the image of the industry, industrial location, the availability of other jobs for whites, and government action." ${ }_{5}$ These factors also caused whites to look elsewhere for jobs, which left a greater share of transit jobs to African-Americans. Simultaneously, a trend in the transit industry was developing. Transit companies in smaller communities were going out of business and those in larger communities (urban areas) were being purchased and operated by public bodies. These two trends increased the participation rate of African-Americans in transit and it appears that they will continue in the future.

\section{INDUSTRIAL LOCATION}

"The transit companies, almost by definition, are urban oriented and located." As African-Americans migrated from the south to cities in the north during the early 1950s, they began to take over transit positions that whites left for opportunities in the suburbs. This enabled African-Americans to meet the labor demands in transit. In addition, many large transit companies in northern cities were experiencing problems of violence and disorder. Since fares were collected and carried on buses, the concern for better security was heightened. In most cities, operating a bus or train was considered "hazardous duty," which helped to decrease white interest in transit further. These problems have been lessened by innovations in revenue policy and operating practices, such as exact fare requirements and radio communication. Jeffress predicted that these concerns would continue the decline of white employment in the industry, unless severe employment declines in other sectors altered the situation.

\section{MANAGERIAL POLICY}

Jeffress was critical of the transit industry for not affecting diversity in management that should have resulted from early affirmative action programs. When considering the decline in white employment, it was anticipated that a predominantly African-American labor force would expand a similar representation in management. Since many transit properties have been taken over by public entities, management has allowed government to become more active in management decisions and management has been satisfied with meeting government mandates. "Nevertheless, managerial policy has neither been particularly forward looking nor obstructive." Given the labor market and working environment, Dr. Jeffress expected a continued increase in the percentage of African-Americans in transit. Additionally, with support from the public sector, government was expected to continue to be a significant part of the transit industry.

\section{UNION POLICY}

Jeffress regarded unions as nondiscriminatory in principal, but not requiring locals to comply or failing to interfere with local policies. Resistance to including African-Americans among transit employees was prevalent in the pre-World War II period. However, the increasing number of African-American transit workers caused union leaders to change their policies, which increased union membership and influence in the transit industry. However, Jeffress described growing discontent among AfricanAmerican union members regarding their status and representation in union leadership. This undoubtedly will be an issue that union officials should resolve to maintain any credibility in the transit industry. 


\section{GOVERNMENT POLICY}

At the time of Jeffress' study, federal assistant programs helped transit overcome the financial problems that contributed to declining service and employment in the industry. This infusion of funds helped public entities to take over control of most transit systems. Because of government control, government had become the "key determinant of racial policy." Many large systems in metropolitan areas reversed the decline in employment, especially for African-Americans. Simultaneously, employment in small town transit systems continued to decline. Jeffress cites several factors related to government policy that will ensure a high proportion of African-Americans', other minorities', and women's employment in transit. These include civil service rules, state laws, federal grant regulations and federal laws that require affirmative action in the employment of minorities and protection against discrimination and continued federal spending, an impetus to the creation of transit jobs in metropolitan areas.

Because of government's influence in the transit industry, several obstacles to African-American advancements were abolished. In addition, government policies that made transit favorable for AfricanAmerican employment resulted in several policy changes in transit. These changes include abolishing union rules barring membership by African-Americans and invalidating separate seniority lists. The latter served as a significant impediment to promotions and made African-Americans vulnerable to bumping since they were usually the newly hired, compared with other employees and would lose seniority if they transferred to another department. Besides government's influence, rapid retirement of workers with greater seniority will encourage promotion among African-Americans. Efforts also were to be directed toward upper management jobs and to political appointments to commissions, governing boards, and public authorities. ${ }^{8}$ Black representation in unions was expected to increase along with power in the transit systems and unions. Jeffress predicted that government policies and other policy changes that affirm minority hiring in transit would help African-Americans maintain a significant role in the industry. He concluded his comments by saying that the urban transit industry would become a black-operated industry serving black riders except where it served as a link between suburban communities and the center city.

\section{INTERVIEW WITH DR. JEFFRESS}

As part of this project, staff consulted with Dr. Jeffress about his study and on other related issues. Jeffress provided anecdotal comments about his original research and his perception of the transit industry. At the outset of the interview, Jeffress said that he had done almost no transportation work since The Negro in the Urban Transit Industry, which was his dissertation work at the University of Kentucky.

The selection criteria for the transit agencies used in Jeffress's research:

- served a big population center;

- a large employer; and

- large ridership.

There also was a desire to have a mix of public and private providers and broad geographic representation. As a result, the sample was based more on judgement than randomness. Besides meeting the criteria, agencies had to be willing to participate and have available the necessary information. Jeffress's study was heavily dependent on agencies' data collection practices. The research also took a journalistic approach and provided descriptive statistics as opposed more in-depth analysis. (Consideration must be given to the fact that the Civil Rights and Federal Transit Acts had only been enacted in 1964. Jeffress's dissertation was published in 1970.) 
Dr. Jeffress stated in the interview, overall, transit outcomes relate to land-use issues. These include the need in most areas for a regional transit system due to urban sprawl, the "urban" nature of most metropolitan areas, and the location of various employment, medical, and social centers. The developments in the telecommunications industry and the subsequent growth of home and satellite offices may exacerbate transit problems.

From an economic perspective, Jeffress said that the more transit must respond to non-market decisions, such as the American with Disabilities Act, the Older Americans' Act, and so on, the more transit must be supported by non-market funds. (Since almost its inception, public transportation has had non-market goals. $)^{9}$ According to Jeffress, transit is not a clear public good. It may only be a quasi-public good, needing private support. From the skeptic's point of view, such an arrangement may not be good for transit. The skeptic may feel that there is no longer an opportunity for affirmative action and the role that transit can play in meeting these objectives. Additionally, the skeptic is not likely live on society's fringes. The growing incidence of crime in inner cities causes additional white flight [out to the suburbs]. Although most crime in inner cities is black-on-black, the perception, in most circumstances, is inner cities and transit are not safe.

Regarding transit's role in providing accessibility to jobs within the industry, Jeffress said he was not surprised by evidence of the "glass ceiling." He intimated that the phenomenon may be a question of political backlashminorities and women may have been expected to "stay in their places" within the industry.

Although Jeffress said that he had not kept up with current transit issues, he discussed the 1970 to 1990 demographics, especially as they related to continued urban sprawl, transit funding, and the emphasis on increased public participation. Jeffress contrasted the current political atmosphere with that of the 1960s and 1970s. He said the effect of the earlier period was that people felt comfortable in opposition. In the current climate affirmative action may be perceived as a barrier or individuals may feel that there are other solutions. He added that there also is a "done all we can do" or some anti-affirmative action sentiment coupled with the desire to try other solutions for balance.

\section{TRANSIT SERVICE AND EMPLOYMENT FROM 1970 THROUGH 1990}

This section contains information on employment in the transit industry from 1970 through 1990 and includes data on productivity and ridership. These data were collected from the American Public Transit Association (APTA), an international organization, representing more than 1,000 motor bus and rapid transit systems. Trends for these data are presented in tables and graphs.

Minorities' and women's employment in transit also are examined in this section. Data from the Census and the Bureau of Labor Statistics (BLS) are used, to a limited extent, to analyze minority employment in transit. Information from Equal Employment Opportunity Commission (EEOC) for selected transit systems is reviewed to assess changes in minorities' and women's employment opportunities and provide a sample changes in the industry. In addition, a survey was conducted to gather salary and experience data and social equity perceptions of minorities and women who work in the transit industry. Information from this survey is presented. 


\section{EMPLOYMENT}

As shown in Table 1 and Figure 1, during the decades of 1970, 1980, and 1990, transit employment reversed the decline experienced since 1950. The total number of employees in all forms of transit service fell from 240,000 in 1950 to 136,040 in 1970 , a decline of approximately 76 percent. In 1975 , transit employment grew to 159,800 , an increase of approximately 16 percent over the employment figure for 1970 .

Transit employment continued to increase during the decade of the 1980s. It grew from 187,000 in 1980 to 270,020 in 1985 , an increase of approximately 44 percent. In 1990, transit employment was 276,192 , 15 percent over the 1950 rates. Data show that employment increased slightly between 1990 and 1992. The most recent available data on transit show that in 1993 it took more than 291,000 employees to operate, maintain, and administer transit service. About 179,000 of those are employed in motor-bus service, 52,400 in heavy rail, 29,000 in demand response, 22,000 in commuter rail, and the balance in other modes. Of the total, operators and conductors on board the vehicles comprised 40 percent, maintenance personnel, 27 percent, and all other, 24 percent. In addition, there were 11,000 capital employees. Perhaps 10,000 to 20,000 other persons are employed by manufacturers of transit equipment, consultants, engineering firms, local governments, and other transit-related businesses.

Figure 1

Trend of Transit Employment

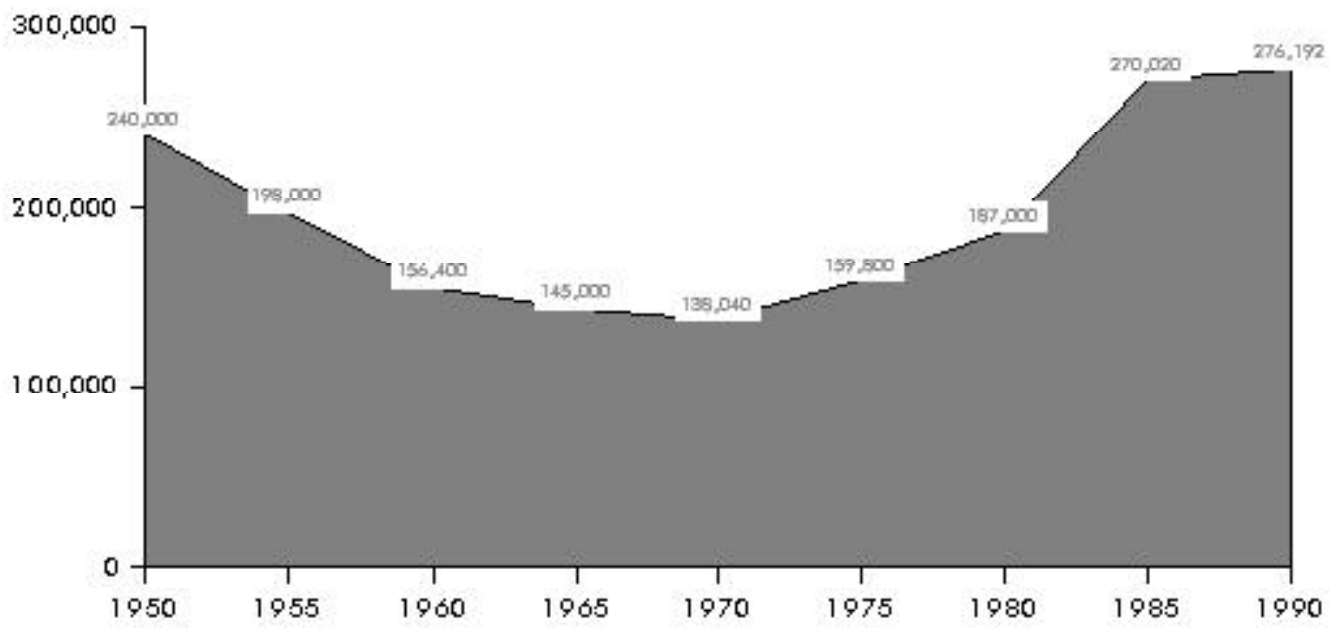

Source: American Public Transit Association (APTA) 1991 Transit Fact Book

In 1970, transit carried 7.3 billion passengers, slightly less than the number of passengers carried in 1965. Transit ridership increased to approximately 8.5 billion in 1975, an increase of 14 percent. This trend continues up to 1990 when public transit systems carried approximately 8.7 billion passengers. The slight fluctuations in transit ridership are significant in this study, since employment opportunities in transit are related to market condition, ridership. Data show that transit ridership remained stable from 1990 to 1992. 
Table 1

Transit Industry 1935 through 1990

\begin{tabular}{|l|llllll|}
\hline \hline Year & $\begin{array}{l}\text { Total Passengers } \\
\text { (Millions) }\end{array}$ & $\begin{array}{l}\text { Total Transit } \\
\text { Vehicles }\end{array}$ & $\begin{array}{l}\text { Transit } \\
\text { Employees }\end{array}$ & $\begin{array}{c}\text { Passengers } \\
\text { Per Employee }\end{array}$ & $\begin{array}{c}\text { Passengers } \\
\text { Per Vehicles }\end{array}$ & \multicolumn{2}{c|}{$\begin{array}{l}\text { Employees } \\
\text { Per }\end{array}$} \\
\hline & & & & & & \\
$\mathbf{1 9 3 5}$ & 12,243 & 74,844 & 209,000 & 58.5 & 163.3 & 2.8 \\
$\mathbf{1 9 4 0}$ & 13,130 & 75,464 & 203,000 & 64.5 & 173.6 & 2.7 \\
$\mathbf{1 9 4 5}$ & 23,368 & 89,758 & 242,000 & 96.1 & 259.1 & 2.7 \\
$\mathbf{1 9 5 0}$ & 17,301 & 86,310 & 240,000 & 71.9 & 200.0 & 2.8 \\
$\mathbf{1 9 5 5}$ & 11,569 & 73,089 & 198,000 & 58.2 & 158.0 & 2.7 \\
$\mathbf{1 9 6 0}$ & 9,395 & 65,292 & 156,400 & 60.1 & 143.9 & 2.4 \\
$\mathbf{1 9 6 5}$ & 8,253 & 61,717 & 145,000 & 57.0 & 133.7 & 2.3 \\
$\mathbf{1 9 7 0}$ & 7,332 & 61,298 & 138,040 & 53.1 & 119.6 & 2.2 \\
$\mathbf{1 9 7 5}$ & 7,284 & 62,183 & 159,800 & 38.9 & 117.1 & 2.2 \\
$\mathbf{1 9 8 0}$ & 8,567 & 75,388 & 187,000 & 45.8 & 113.6 & 2.5 \\
$\mathbf{1 9 8 5}$ & 8,636 & 94,368 & 270,020 & 32.0 & 91.5 & 2.9 \\
$\mathbf{1 9 9 0}$ & 8,799 & 92,961 & 272,839 & 32.3 & 94.7 & 2.9 \\
$\mathbf{1 9 9 1}$ & 8,575 & 96,399 & 276,145 & 31.1 & 89.0 & 2.9 \\
$\mathbf{1 9 9 2}$ & 8,501 & 102,251 & 278,995 & 30.5 & 83.1 & 2.7 \\
\hline
\end{tabular}

Source: APTA Website: http://apta.com, 1996.

Figure 2

Trend of Transit Ridership

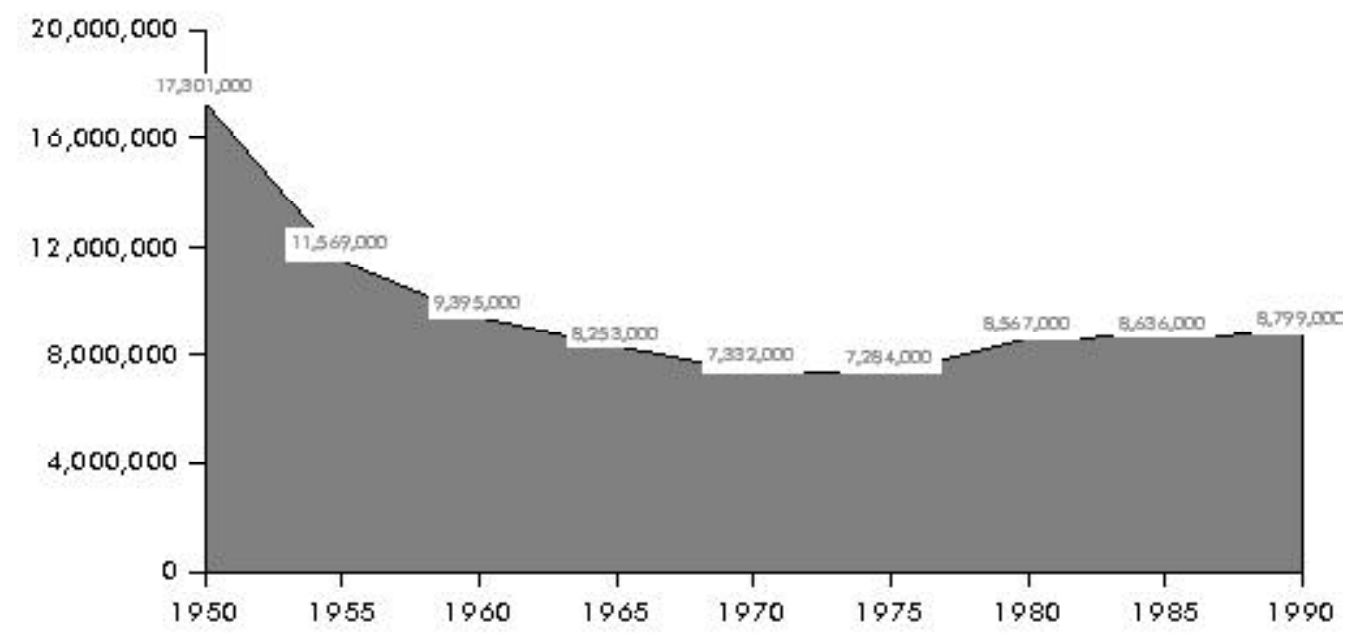

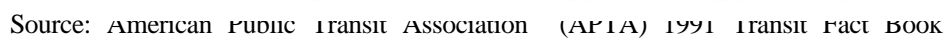


Another review of Table 1 shows that in 1970 transit carried approximately 53.1 passengers per each employee. The number of passengers to employees may be viewed as a rough estimate of the demandlabor ratio. This ratio declined to 45.8 passengers-to-employees in 1980 and 32.3 passengers-to-employees in 1990. The ratio of passengers per each employee declined by 64 percent between 1970 and 1990. This ratio remained stable between 1990 and 1992. In addition, data in the Nationwide Personal Travel Survey (NPTS) show a trend of general decline in transit for all trips. The 1977 NPTS showed a transit share of 2.4 percent of person trips, declining to 2.2 percent in 1983 , and finally to 2.0 percent in 1990 .

Although the decrease is evident for the period between 1970 and 1990, the greatest part of the decline may be explained by examining the changes in ridership and travel behavior during this period. Changes in travel demand by women, minorities, and low-income populations have reduced the tendency of these groups to use transit. To understand the nature of this decline, a separate section of this paper discusses the changes in transit demand in greater detail.

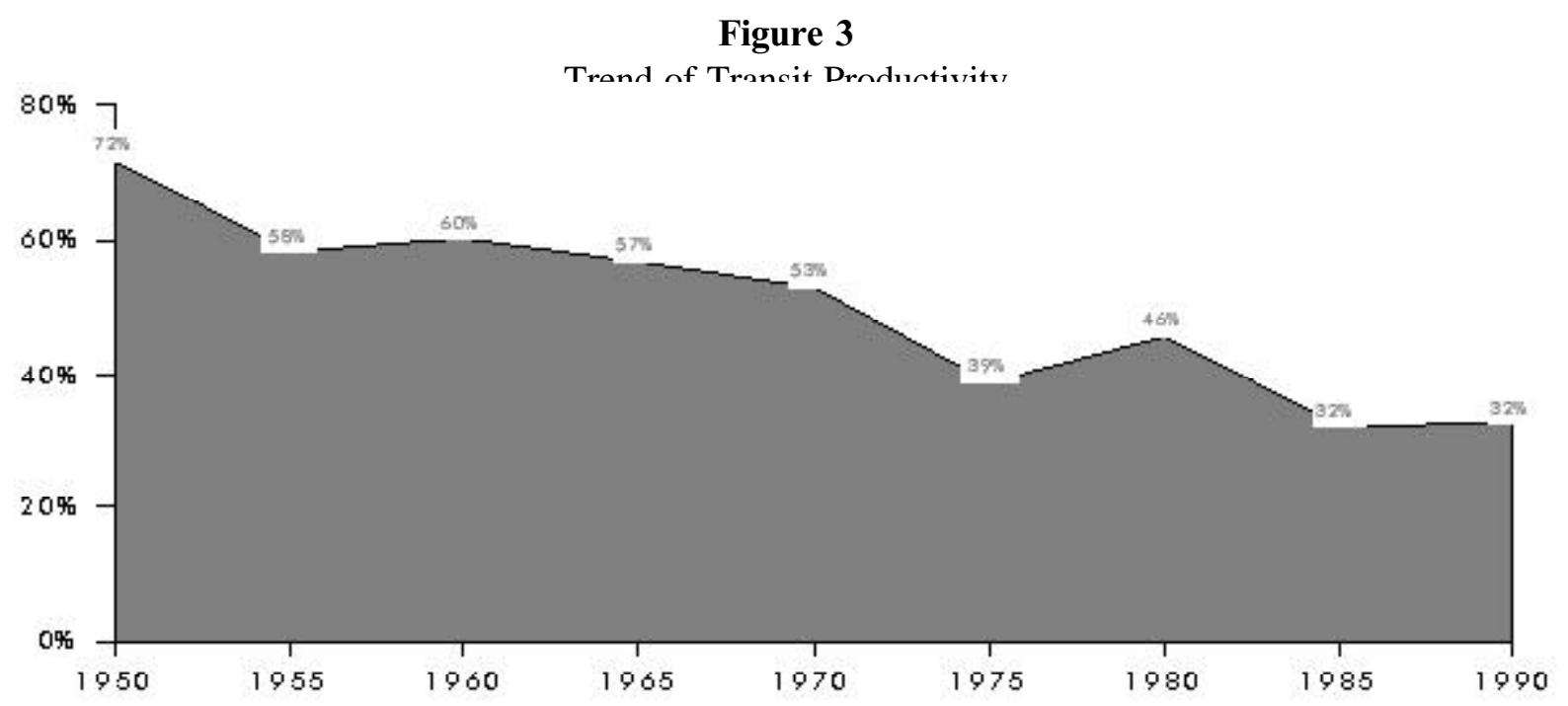

Source: American Public Transit Association (APTA) 1991 Transit Fact Book

\section{MINORITY EMPLOYMENT}

In collecting data on minority employment in transit, information was compiled from three sources. They include 1970 and 1980 Censuses: Industry of Employed Persons; Bureau of Labor Statistics: 1990 Current Population Survey (CPS); and the Reports EEO-1 and EEO-4 for responding transit systems.

Besides providing statistical data relating to the social and economic activities and characteristics of the population of the United States, census information gives a summary of employed persons for various industries. The CPS, a monthly household survey, conducted by the Bureau of the Census for the Bureau of the Labor Statistics (BLS), provided a comprehensive body of information on the employment and unemployment experience of the nation's population, classified by age, sex, race, and a variety of other characteristics. During the early 1970s, transit systems were excluded from coverage of Title VII of the Civil Rights Act of 1964 and were not required to file racial data with the EEOC. According to the EEOC, as part 
of its mandate under the amended Title VII of the Civil Rights Act of 1964, public and private employers, unions, and labor organizations are required to submit period reports showing the makeup of their workforce by sex, race, and ethnic categories as defined in the U. S. Department of Commerce, Office of Federal Statistical Policy and Standards Directive Number 15. The data collected from these reports are used by the EEOC to aid it in carrying out its enforcement responsibilities. Samples of this data are used later to show the progress of minorities and women in the transit industry from 1984 to 1993.

The Commission currently requires the filing of five types of reports; EEO-1 employer information report (annual); EEO-3 local union (biennial); EEO-4 state and local government information report (annually for 100 or more employees); EEO-5 elementary secondary staff information report (biennial); and EEO-6 higher education staff information report. Report EEO-4 is used to measure patterns of employment and identify areas of discrimination and progress. It does not measure "availability," an important factor in showing employer policies or practices that may have an "adverse impact" on the employment opportunities of any race, sex, or ethnic group. Report EEO-4 data differ from census and BLS information, which are based on individual responses to questionnaires. EEO-4 data are compiled from employer payroll data submitted to the Commission.

There are, however, limitations to the usefulness of these data.

- The census and BLS data for this study may include privately owned charter and school bus operators along with urban transit systems.

- Data comparable to 1970 and 1980 census figures do not exist for 1990. Employ ment for the transit industry is reported as "street railways and bus lines" in the 1970 census and "bus service and urban transit" in the 1980 census. A thorough search of the census revealed that transit is not reported as an industry in 1990. Thus, information from the BLS - CPS is used instead of the census to examine minorities' and women's employment in transit for 1990.

- These data also differ in that the census includes race categories for Whites, AfricanAmericans, Hispanic, Native Americans, and Asians. CPS data do not comprise all population groups since the Hispanic, Native American, and Asian populations were too small to provide statistical estimates that are reliable. For the purposes of this paper, all minority groups have been combined.

- Although the original Federal Transit Act required all grant recipients (i.e., transit systems) to make and keep records and statistics for completion of Report EEO-4, records must only be retained for three years. The most comprehensive set of Report EEO-4 data that can be used in this analysis are available for 1984, 1985, 1989, 1991, and 1993. This information serves as a sample of minority and women employment in transit.

According to Jeffress's study, the 1960 census reported transit employment at 288,488. The data also show that employment was approximately 36 percent lower in 1970. Table 2 shows that total employment in transit increased by 106 percent between 1970 and 1980. Minorities in transit increased as a percentage of total employment during this period by 236 percent. When considered alone, the CPS data show that minorities makeup a significant share of transit's workforce in 1990, representing 28 percent of transit workers. This data appears consistent with that of the census for the preceding decades.

These data also show similar percentages for women. Not only have women maintained a significant share of the jobs in transit, but the percentage increased slightly between 1970 and 1980. Similarly, the CPS data show that women represent approximately 31 percent of transit workforce in 1990. 
Table 2

Transit Industry Employment by Ethnicity/Race and Sex 1970, 1980, and 1990

\begin{tabular}{|l|lllllll|}
\hline Year & Total & White & Percent & Minorities & \%o of total $\begin{array}{c}\text { Women\% } \\
\text { of total }\end{array}$ \\
\hline $\mathbf{1 9 7 0}$ & 183,637 & 150,154 & 82 & 33,483 & 18 & 44,003 & 24 \\
$\mathbf{1 9 8 0}$ & 378,762 & 266,183 & 70 & 112,579 & 30 & 101,166 & 27 \\
$\mathbf{1 9 9 0}$ & 468,000 & 337,000 & 72 & 115,000 & 25 & 147,000 & 31 \\
\hline
\end{tabular}

Source: U. S. Census Data, 1970 and 1980; Bureau of Labor Statistics, 1990.

The 1970 and 1980 censuses and the 1990 CPS illustrate an interesting trend in transit employment. A significant finding in Jeffress's study of the transit industry was that between 1945 and 1960 the number of African-American employees increased while transit employment had declined. Since 1970, employment in this industry has increased, as has employment for minorities and women. Between 1970 and 1980, the percentage of white employees in transit declined from approximately 81 percent to 70 percent, minority employees grew from 18 percent to 29 percent, and women employees increased from 24 percent to 26 percent. The CPS data for 1990 show that 72 percent of transit employees are white, 28 percent are minorities, and women represent approximately 31 percent. These data infer that the progress made by minorities during the previous decades is being reversed, that the number of white employees has increased between 1980 and 1990 and that women are increasing their share of employment in this industry.

The analysis also suggests that transit is becoming more accessible to women. The number of women in the workforce has increased significantly during the past three decades. It also may serve as an indication of the impacts of affirmative action programs and policies on employment selection procedures in transit. What is most important, however, it may corroborate the claim by many affirmative action proponents who argue that women, especially white women, benefit most from programs designed to bring diversity to the workplace.

To assess employment opportunities for minorities in transit, Report EEO-4 data were requested from 19 transit systems. These systems are presented in Table 3. The systems in the sample were selected using employment size and service area population as criteria. This criterion was used to include the greatest possible number of people potentially affected by transit policy and because major transit systems are found in the largest metropolitan areas. Additionally, using the systems with the most employees enlarges the total sample with a given number of systems. A similar survey methodology was used in Jeffress's study. Data in the 1993 Section 15 Report that provides detailed summaries of financial and operating data submitted to FTA by the nation's mass transit agencies, reported that the transit systems included in the sample comprised nearly half (45\%) of transit employment in 1993.

In preparing for this analysis, Report EEO-4 data were requested for 1980 through 1994. If these reports were archived over the years, the data would provide the best sample to evaluate the progress of minorities' and women's employment in transit. As noted in the introductory paragraph of this section, a limitation of the Report EEO-4 data is that agency records must only be retained for three years. Resulting from this policy, the information received was incomplete. However, the information received is the most comprehensive data available and serves as a sample of employment in the transit industry. It includes systems in the following major metropolitan areas: Minneapolis, Baltimore, Chicago, Philadelphia, Miami, Washington, New York City, Atlanta, New Jersey, Houston, and San Francisco. ${ }^{10}$ This information was available for 1984, 1985, 1989, 1990, 1991 and 1993. 
Table 3

List of Transit Systems

\begin{tabular}{|l|}
\hline \hline New York City Transit Authority (NYCTA) \\
Long Island Rail Road Company (LIRR) \\
Chicago Transit Authority (CTA) \\
Los Angeles Metropolitan Transportation \\
Washington Metropolitan Area Transit Authority \\
Massachusetts Bay Transportation Authority - Boston \\
Southeastern Pennsylvania Transportation Authority - Philadelphia \\
San Francisco Municipal Railway \\
New Jersey Transit Corporation \\
Metropolitan Atlanta Rapid Transit Authority \\
Mass Transit Administration - Baltimore \\
Metropolitan Transit Authority of Harris County - Houston \\
Municipality of Metropolitan Seattle \\
San Francisco Bay Area Rapid Transit District \\
City of Detroit Department of Transportation \\
Port Authority of Allegheny County - Pittsburgh \\
Metro-Dade Transit Agency - Miami \\
Regional Transit Agency - New Orleans \\
Metropolitan Transit Commission - Minneapolis \\
\hline
\end{tabular}

Of the transit systems that could provide equal employment opportunity reports (EEO), eleven transit systems provided EEO-4 reports and one provided EEO-1 reports for the years 1984 through 1993. Table 4 displays a comparison of employees in the transit industry with the aggregated data obtained from the EEO-4 reports collected from the participating agencies.

Table 4

Sample of Transit Employees in Study

\begin{tabular}{|c|c|c|c|c|}
\hline Year & $\begin{array}{l}\text { Number of } \\
\text { Transit Systems }\end{array}$ & $\begin{array}{l}\text { Number of Employees } \\
\text { in Transit }\end{array}$ & $\begin{array}{l}\text { Number of Employees } \\
\text { in Transit Industry }\end{array}$ & $\begin{array}{l}\text { \% of Employees } \\
\text { in the Transit Industry }\end{array}$ \\
\hline 1984 & 10 & 47,119 & 263,197 & 18 \\
\hline 1985 & 10 & 47,623 & 270,020 & 18 \\
\hline 1989 & 11 & 110,511 & 272,487 & 41 \\
\hline 1990 & 11 & 103,018 & 272,839 & 38 \\
\hline 1991 & 12 & 111,731 & 276,145 & 40 \\
\hline 1993 & 12 & 112,266 & 302,758 & 37 \\
\hline
\end{tabular}

Source: 1984 Report EEO-4.

Tables 5 through 10 illustrate the trend of employment in transit by combining data for the transit agencies included in the sample. Note, the fluctuation in sample sizes for the years is due to incomplete data. 
Table 5

Transit Population Sample for $1984^{11}$

\begin{tabular}{|l|rrrrrrr|}
\hline \hline Occupational Group ${ }^{12,13}$ & White & \%Total & Minorities & \%Total & Women & \%Total & Total \\
\hline & & & & & & & \\
Officials/Administrators & 2,046 & 72 & 812 & 27 & 246 & 9 & 2,858 \\
Professionals & 2,075 & 65 & 1,139 & 35 & 792 & 25 & 3,214 \\
Technicians & 513 & 64 & 294 & 36 & 150 & 19 & 807 \\
Protective Services & 505 & 55 & 408 & 45 & 137 & 15 & 913 \\
Para-Professionals & 55 & 56 & 44 & 43 & 47 & 48 & 99 \\
Administrative Support & 2,180 & 45 & 2,647 & 55 & 2,718 & 56 & 4,827 \\
Skilled Craft & 6,879 & 63 & 4,107 & 41 & 259 & 3 & 10,986 \\
Service/Maintenance & 6,527 & 28 & 16,918 & 69 & 2,877 & 12 & 23,445 \\
Total & 20,780 & 44 & 26,369 & 48 & 7,226 & 15 & 47,149 \\
\hline
\end{tabular}

Source: 1984 EEO-4 Reports in the authors' possession.

The largest concentration of women, 2,877, among 1984 respondents is found in the Service/Maintenance occupational group. The second largest, 2,718, is found in the Administrative Support occupational group. The two groups comprise 78 percent of all women employed by respondents for that year. Women held 56 percent of the positions classified as Administrative Support and 48 percent of the positions classified as Para-Professional.

Table 6

Transit Population Sample for $1985^{14}$

\begin{tabular}{|l|rrrrrrrr}
\hline \hline \multirow{2}{*}{ Occupational Group 15,16 } & \multicolumn{2}{|c}{ White } & \multirow{2}{*}{ \%Total } & \multirow{2}{*}{ Minorities } & \multirow{2}{*}{ \%Total } & Women & \%Total & Total \\
\hline Officials/Administrators & 2,226 & 74 & 802 & 26 & 278 & 9 & 3,028 \\
Professionals & 1,793 & 65 & 982 & 35 & 763 & 27 & 2,775 \\
Technicians & 517 & 64 & 295 & 36 & 145 & 18 & 812 \\
Protective Services & 465 & 54 & 393 & 46 & 128 & 15 & 858 \\
Para-Professionals & 43 & 64 & 24 & 36 & 28 & 42 & 67 \\
Administrative Support & 2,238 & 46 & 2,644 & 54 & 2,496 & 51 & 4,865 \\
Skilled Craft & 8,390 & 68 & 4,272 & 34 & 326 & 1 & 12,390 \\
Service/Maintenance & 6,273 & 27 & 15,072 & 66 & 2,278 & 10 & 22,872 \\
Total & 21,945 & 46 & 24,484 & 51 & 6,442 & 14 & 47,667 \\
& & & & & & & & \\
\hline
\end{tabular}

Source: 1985 EEO-4 Reports in authors’ possession.

In 1985, the largest concentration of women, 2,496, is found in the Administrative Support occupational group. The second largest, 2,278, is found in the Service/ Maintenance occupational group. Women in these occupational groups comprise 74 percent of all women employed by respondents in 1985 . Women held 51 percent of the positions classified as administrative support, 42 percent of the para-professional classifications, and 27 percent of the professional classifications. 
Table 7

Transit Population Sample for $1989^{17}$

\begin{tabular}{|l|rrrrrrrr|}
\hline \hline Occupational Group ${ }^{18,19}$ & \multicolumn{2}{|c}{ White } & \%Total & Minorities & \%Total & Women & \multirow{2}{*}{ \%otal } & Total \\
\hline Officials/Administrators & 4,597 & 66 & 2,417 & 34 & 1,137 & 16 & 7,014 \\
Professionals & 3,776 & 59 & 2,656 & 41 & 1,511 & 23 & 6,432 \\
Technicians & 1,304 & 59 & 898 & 41 & 516 & 23 & 2,202 \\
Protective Services & 2,906 & 61 & 1,880 & 39 & 524 & 11 & 4,786 \\
Para-Professionals & 79 & 49 & 83 & 51 & 57 & 35 & 162 \\
Administrative Support & 4,110 & 34 & 8,137 & 66 & 5,947 & 49 & 12,247 \\
Skilled Craft & 17,621 & 50 & 17,657 & 50 & 900 & 3 & 35,278 \\
Service/Maintenance & 11,223 & 26 & 31,750 & 74 & 5,126 & 12 & 42,973 \\
Total & 45,616 & 41 & 65,478 & 59 & 15,718 & 14 & 111,094 \\
& & & & & & & \\
\hline
\end{tabular}

Source: 1989 EEO-4 Reports in authors' possession.

Seventy percent of the women employed by the responding systems fell into the occupational categories of Administrative Support and Service/Maintenance. Women held 49 percent of the positions classified as administrative support; 35 percent of the para-professional classifications; and 23 percent each of the professional and technician classifications.

Table 8

Transit Population Sample for $1990^{20}$

\begin{tabular}{|l|rrrrrrr|}
\hline \hline Occupational Group $^{1,22}$ & White \%Total & Minorities & \%Total & Women & \%Total & \multicolumn{1}{c|}{ Total } \\
\hline Officials/Administrators & 6,640 & 63 & 3,839 & 37 & 1,095 & 10 & 10,479 \\
Professionals & 3,574 & 59 & 2,532 & 41 & 1,444 & 24 & 6,106 \\
Technicians & 1,415 & 62 & 877 & 38 & 312 & 14 & 2,292 \\
Protective Services & 3,064 & 62 & 1,839 & 38 & 663 & 14 & 4,903 \\
Para-Professionals & 116 & 42 & 160 & 58 & 108 & 39 & 276 \\
Administrative Support & 3,706 & 32 & 8,042 & 68 & 5,883 & 50 & 11,748 \\
Skilled Craft & 19,276 & 54 & 16,590 & 46 & 1,473 & 4 & 35,866 \\
Service/Maintenance & 9,933 & 29 & 24,859 & 71 & 3,990 & 11 & 34,792 \\
Total & 47,724 & 45 & 58,738 & 55 & 14,968 & 14 & 106,462 \\
\hline
\end{tabular}

Source: 1990 EEO-4 Reports in authors' possession.

Women comprised 50 percent, or 5,883 employees, of the occupational group, Administrative Support, among responding systems in 1990. The second largest occupational group was Service/ Maintenance, 3,990. Sixty-six percent of all women were found the Administrative Support and Service/Maintenance groups. After Administrative Support, para-professionals and professionals were the next highest groups for women. 
Table 9

Transit Population Sample for $1991^{23}$

\begin{tabular}{|l|rrrrrrrr|}
\hline \hline Occupational Group ${ }^{24,25}$ & White & \%Total & Minorities & \%Total & Women & \%Total & Total \\
\hline Officials/Administrators & 7,592 & 64 & 4,323 & 36 & 1,101 & 9 & 11,915 \\
Professionals & 3,850 & 56 & 3,027 & 44 & 1,706 & 25 & 6,877 \\
Technicians & 1,214 & 59 & 851 & 41 & 275 & 13 & 2,065 \\
Protective Services & 3,118 & 61 & 2,029 & 39 & 783 & 15 & 5,147 \\
Para-Professionals & 141 & 38 & 235 & 63 & 176 & 47 & 376 \\
Administrative Support & 3,271 & 28 & 8,609 & 72 & 6,559 & 55 & 11,880 \\
Skilled Craft & 16,698 & 50 & 16,644 & 50 & 1,393 & 4 & 33,342 \\
Service/Maintenance & 10,817 & 27 & 29,138 & 73 & 4,795 & 12 & 39,955 \\
Total & 46,701 & 42 & 64,856 & 58 & 16,788 & 15 & 111,557 \\
& & & & & & & & \\
\hline
\end{tabular}

Source: 1991 EEO-4 Reports in authors' possession.

Sixty-eight percent of women employed by the respondents were in the occupational groups of Administrative Support and Service/Maintenance. The largest number, 4,559, was found in the Administrative Support group. Women comprised 55 percent, 47 percent, and 25 percent of the Administrative, Para-Professional, and Professional occupational groups, respectively.

Table 10

Transit Population Sample for $1993^{26}$

\begin{tabular}{|l|rrrlrrr|}
\hline \hline Occupational Group $^{27,28}$ & \multicolumn{1}{|c}{ White } & \%Total & Minorities & \%Total & Women & \%Total & \multicolumn{1}{c|}{ Total } \\
\hline Officials/Administrators & 7,156 & 62 & 4,408 & 38 & 1,453 & 13 & 11,564 \\
Professionals & 3,895 & 53 & 3,457 & 47 & 1,856 & 25 & 7,352 \\
Technicians & 1,144 & 60 & 773 & 40 & 333 & 17 & 1,917 \\
Protective Services & 2,940 & 53 & 2,649 & 47 & 976 & 17 & 5,589 \\
Para-Professionals & 264 & 45 & 322 & 55 & 117 & 20 & 586 \\
Administrative Support & 3,324 & 25 & 9,923 & 75 & 6,712 & 51 & 13,247 \\
Skilled Craft & 15,774 & 51 & 15,431 & 49 & 1,429 & 5 & 31,205 \\
Service/Maintenance & 10,711 & 26 & 29,787 & 74 & 5,244 & 13 & 40,498 \\
Total & 45,208 & 40 & 66,750 & 60 & 18,120 & 16 & 111,958 \\
& & & & & & & \\
\hline
\end{tabular}

Source: 1993 EEO-4 Reports in authors' possession.

The largest number of women, 6,712, employed by respondents was found in the Administrative Support occupation group. Combined with Service/Maintenance, these two groups comprised 66 percent of women employed by respondents. Women represented 51 percent, 25 percent, and 20 percent of the Administrative Support, Professional, and Para-Professional occupational groups, respectively.

Information in Tables 5 through 10 is aggregated for each year in the sample by white, minorities, and women. The totals are presented in Table 11. Noting that the analysis shows a significant increase in the sample size between 1985 and 1989 is important. This is due, primarily, to the increase in the number of Report EEO-4 received from various transit agencies. The sample size, however, remained stable for the years 1989, 1990, 1991, and 1993, fluctuating between 43 percent and 47 percent of transit's total 
population. During these years, minorities represented over half the employment for the transit agencies in the sample. Similarly, the proportion of women in the sample had a steady growth during the years represented. The proportion of white employees in the sample declined.

There are some consistencies between the transit population sample and the previous analysis of census and BLS information on minorities' and women's employment from 1970 to 1990 . These data suggest that the proportion of these population groups in transit have increased between 1970 and 1980, and has continued through the early portion of the 1990s. Both data sets show that transit employment grew during these periods. This growth is constant for women and their share of transit's workforce. However, contrary to the earlier conclusion that the progress made by minorities between 1960 and 1980 is being reversed, the transit population samples show that the number and proportion of minorities in transit had persistent growth during the early part of the 1990s. Additionally, the data showed white employment in transit fluctuated between 1989 and 1993, but declined in proportion to total transit employees. The analysis of the Census and BLS data showed an increasing trend in the number of white employees between 1980 and 1990.

Table 11

Aggregate of Transit Employees from Sample Agencies

\begin{tabular}{|l|ll|ll|ll|r|}
\hline \hline Year & White & \%Total & Minorities & \%Total & Women & \%Total & Total \\
\hline $\mathbf{1 9 8 4}$ & 20,780 & 44 & 26,369 & 56 & 7,226 & 15 & 47,149 \\
$\mathbf{1 9 8 5}$ & 21,945 & 47 & 24,484 & 53 & 6,442 & 14 & 46,429 \\
$\mathbf{1 9 8 9}$ & 45,616 & 41 & 65,478 & 59 & 15,718 & 14 & 111,094 \\
$\mathbf{1 9 9 0}$ & 47,724 & 45 & 58,738 & 55 & 14,968 & 14 & 106,462 \\
$\mathbf{1 9 9 1}$ & 46,701 & 42 & 64,856 & 58 & 16,788 & 15 & 111,557 \\
$\mathbf{1 9 9 3}$ & 45,208 & 40 & 66,750 & 60 & 18,120 & 16 & 111,958 \\
Average & 37,996 & 43 & 51,113 & 57 & 13,210 & 15 & 89,108 \\
\hline
\end{tabular}

Source: Data in authors' possession.

Jeffress predicted that transit would become an industry owned and operated by African-Americans. The data for the agencies in the sample show that since Jeffress's study, not only have African-Americans increased their share of transit's workforce, but the proportion of other minorities and women in transit have also increased. In view of the data presented here, what has been the progress of minorities and women into transit management? Another review of the data in Tables 5 through 10 provides an opportunity to measure the progress of minorities and women into management positions for the transit agencies in the sample. An aggregate of the employees classified as "official/administrators and professionals" is used to assess the progress of minorities and women to these ranks. ${ }^{29}$ 
Table 12

Aggregate of Transit Employees - Management Positions

\begin{tabular}{|l|ll|ll|ll|r|}
\hline \hline Year & White & \%Total & Minorities & \%Total & Women & \%Total & Total \\
\hline $\mathbf{1 9 8 4}$ & 4,121 & 68 & 1,951 & 32 & 1,038 & 17 & 6,072 \\
$\mathbf{1 9 8 5}$ & 4,019 & 69 & 1,784 & 31 & 1,041 & 18 & 5,803 \\
$\mathbf{1 9 8 9}$ & 8,373 & 62 & 5,073 & 38 & 2,648 & 20 & 13,446 \\
$\mathbf{1 9 9 0}$ & 10,214 & 62 & 6,371 & 38 & 2,539 & 15 & 16,585 \\
$\mathbf{1 9 9 1}$ & 11,442 & 61 & 7,350 & 39 & 2,807 & 15 & 18,792 \\
$\mathbf{1 9 9 3}$ & 11,051 & 58 & 7,865 & 42 & 3,309 & 17 & 18,916 \\
Average & 8,203 & 62 & 5,066 & 38 & 2,230 & 17 & 13,269 \\
\hline
\end{tabular}

Source: Data in authors' possession.

Table 12 presents information on management positions for the transit systems in the sample. The data seem consistent with the previous analysis of transit employment which showed an increase in minorities' and women's employment during the decades of 1970 and 1980, and the early 1990s. For 1989, 1990, 1991 and 1993, the years with the largest samples, the data show that minorities and women made progress into management ranks, in numbers and their shares of these positions. It also shows that the share of white employees in these positions declined. In 1993, the most recent year for data in the sample of transit agencies, minorities represented approximately 39 percent of management positions; women represented 15 percent. It is possible that the number of minorities in management is larger as the above aggregate excludes supervisors and managers for other occupational groups.

\section{MINORITIES AND WOMEN IN TRANSIT SURVEY}

The minorities and women in transit survey was conducted to gather salary, experience, and social equity perceptions of minorities and women the industry. In view of Jeffress's predictions about transit becoming an industry mostly operated and owned by African-Americans, the survey also served as an model of the progress that minorities and women have made into management positions. The survey design was taken from the American Planning Association 1991 Planners Salary Survey Form. A random sample of 500 was drawn from the membership rosters of the National Forum for Black Public Administrators $(\mathrm{NFBPA})^{30}$, Conference of Minority Transportation Officials (COMTO), Women's Transportation Seminar (WTS), and APTA's Minority Affairs Committee (MAC). The first mailing was made in August 1995; a second mailing took place in September 1995. A total of 297 usable surveys was returned for a response rate of 59 percent. A copy of the survey instrument is contained in Appendix A. Responses and selected comments are presented in Appendix B. The final survey question asked if respondents were interested in participating in a telephone interview. Information from the interviews is presented in Appendix C.

Response frequencies and comments regarding the perceptions of minorities and women in transit follows. The comments are limited to introducing subjects and brief interpretations of findings. Frequencies include gender, ethnicity, age, agency status, years of experience, income, education, and certification or license. Information is presented on programs that respondents have participated which are designed to enhance 
diversity in public service, including mentoring and affirmative action programs. Respondents' perceptions on minority progress in transit during the last ten years are evaluated and compared with other industries. In sampling salary disparities between minorities and non-minorities and between the sexes, data is provided on respondents' perceptions about sexual, racial, and ethnic discrimination. Lastly, information was requested from respondents about their perceptions of affirmative action.

\section{PROFILE OF RESPONDENTS AND QUALIFICATIONS}

Figures 4 through 7 provide characteristics of respondents. Approximately 54 percent were women and 83 percent said they were members of a minority group. The largest group of the respondents was Black of Non-Hispanic Origin; they made up approximately 72 percent of the respondents. The median age reported by the respondents was 45 years and the median salary was $\$ 62,671$. Respondents were asked to indicate the highest degree earned. Forty-two percent said a master's degree; 34 percent, a bachelor's degree. Since the respondents were asked to show the highest degree earned, it is possible that the number of respondents with a bachelor's degree is higher than reported. It is more than likely that those respondents with masters' degrees also have bachelor's degrees. This probably is true for the respondents that said they had a Ph.D. Over half the respondents (52\%) do not have any certification or licensure.

Respondents were asked to indicate if they participated in any of the following programs.

- A Better Chance

- APTF Transit Hall of Fame Scholarship

- Upward Bound

- Urban League

- USDOT Summer Transportation Internship

Of the 297 respondents, less than 25 percent said they had participated in one of these programs.

Figure 4

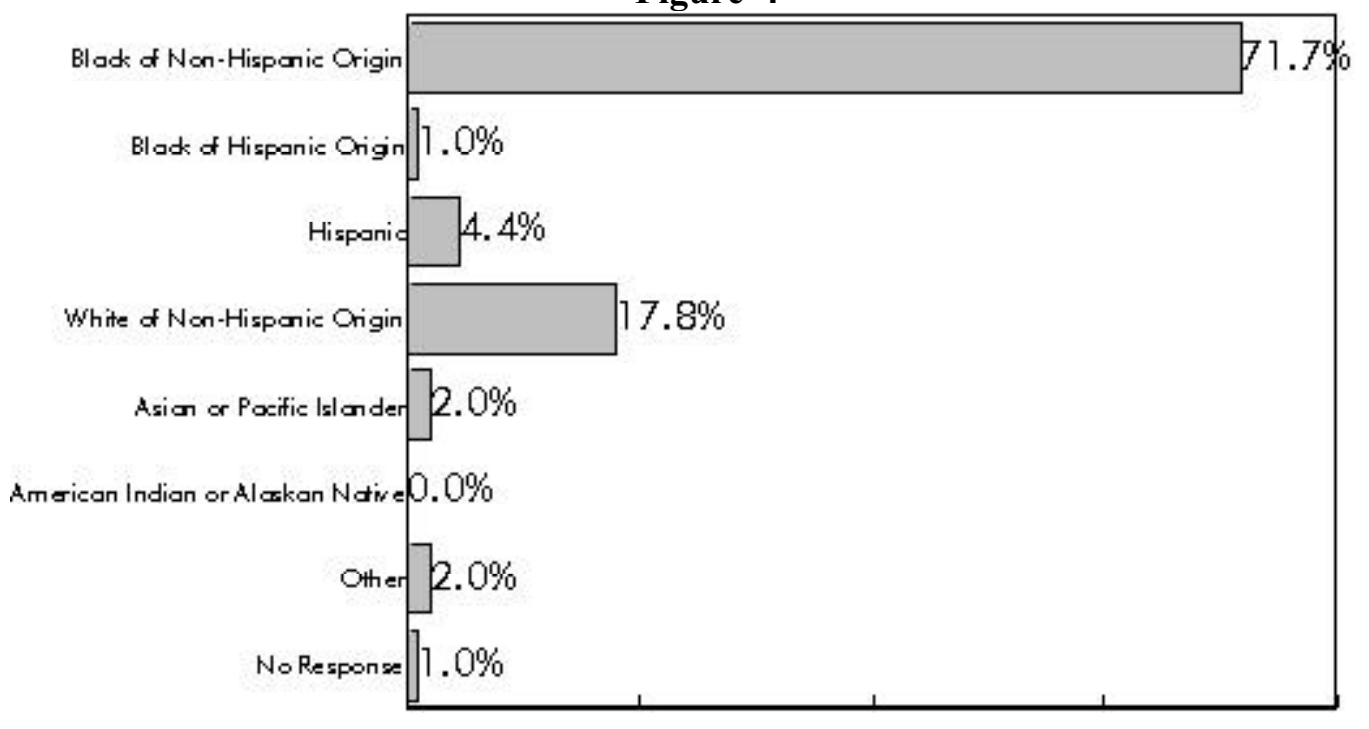


Figure 5

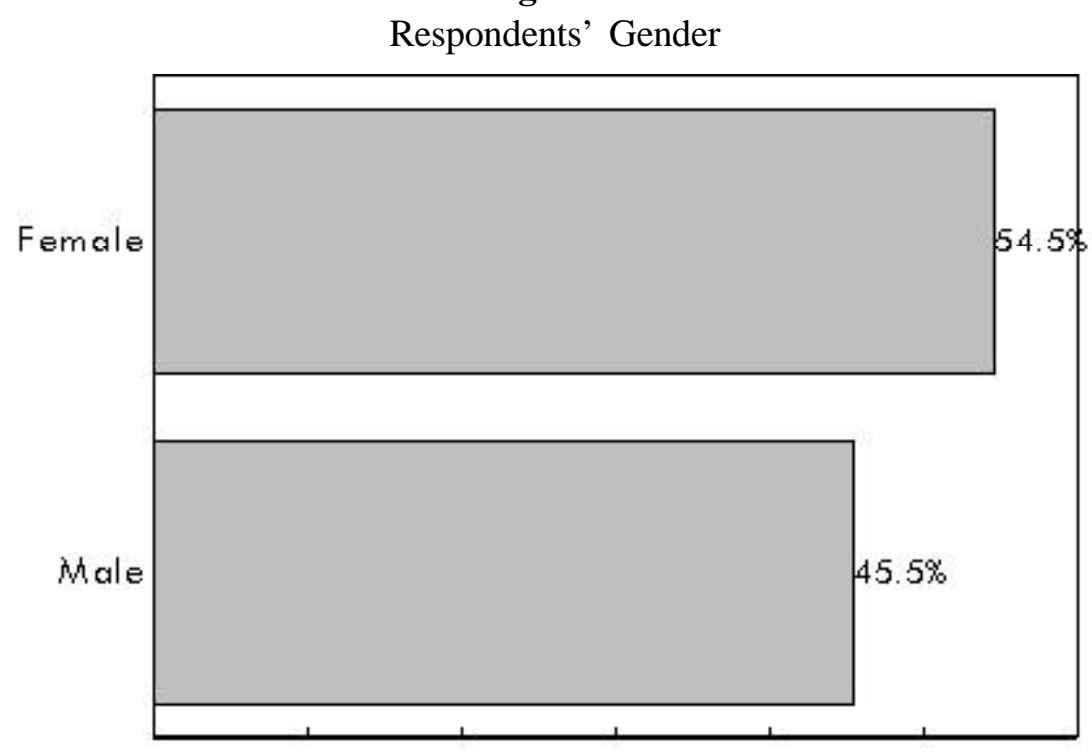

Figure 6

Respondents' Job Categories

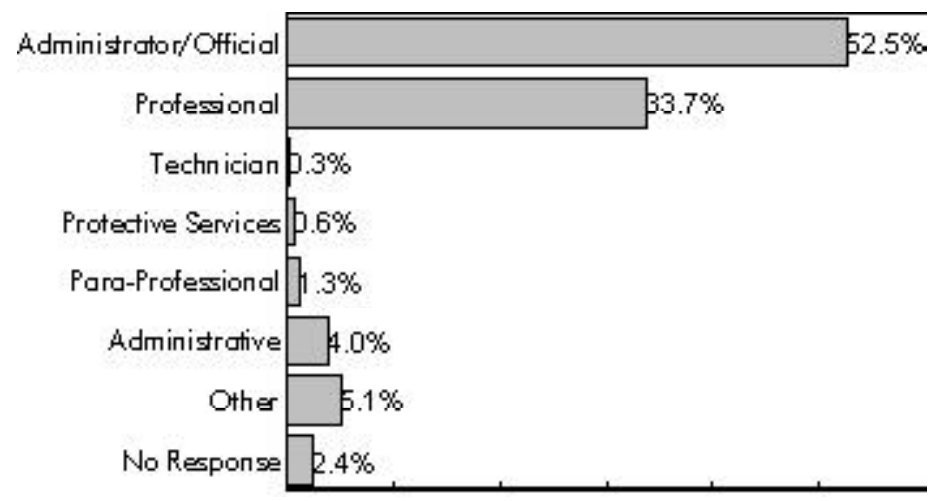

Figure 7

Highest Degree Earned by Respondents

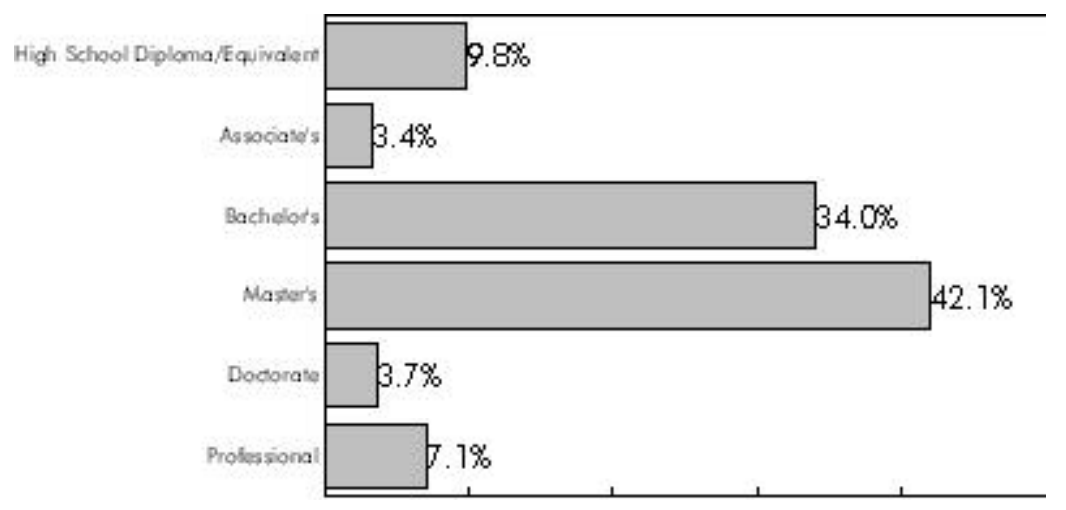


Most of the respondents worked for public agencies. Approximately 53 percent of the respondents described their current job category as Administrator/Official. The job category with the second highest response rate was Professional, 33 percent. For this analysis, respondents that described their current job category as Technician, Para-Professional, or Protective Services, were grouped together since individually their numbers were too small to be significant. Approximately 38 percent of respondents said they had more than 15 years' experience in the transit industry; 27 percent said they had between 5 and 10 years of experience. Respondents also were asked to give the number of years they have been in their current position. Seventy percent said five years or less.

\section{Social Equity Perceptions}

The survey provided information on perceptions of discrimination in transit. Respondents to the survey were asked their opinions of the progress of minorities and women in transit during the past 10 years. Most respondents stated that minorities have made progress.

Approximately 55 percent respondents thought that the percentage of minorities and women in senior or management positions had increased and 52 percent thought that progress had occurred in their agencies. These perceptions were consistent with the findings from the sample EEO report data that suggests that the share of minorities and women in management positions has increased in recent decades. When compared with other industries, 42 percent of the respondents stated the percentage of minorities in transit is greater.

\section{Figure 8}

Do you think that the percentage of minorities and women in senior or management positions in the transit industry has...

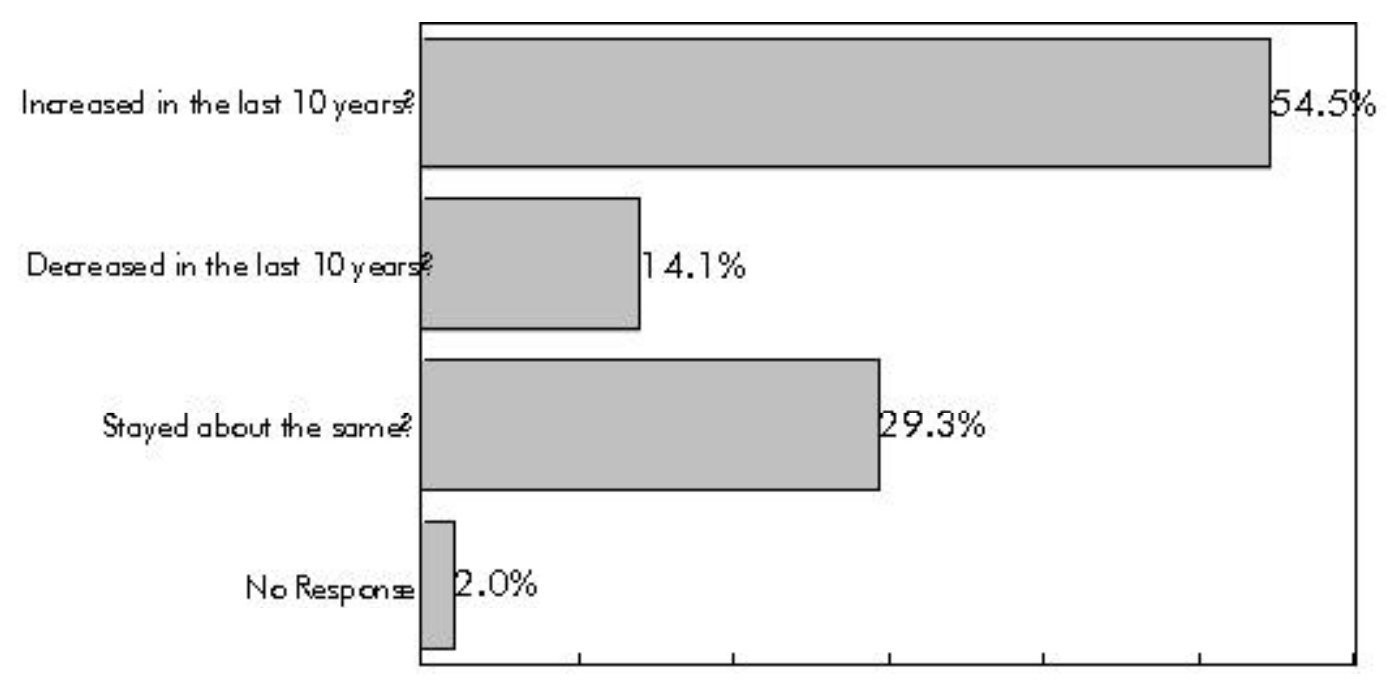




\section{Figure 9}

Do you think that the percentage of minorities and women in senior or management positions in the transit industry has...

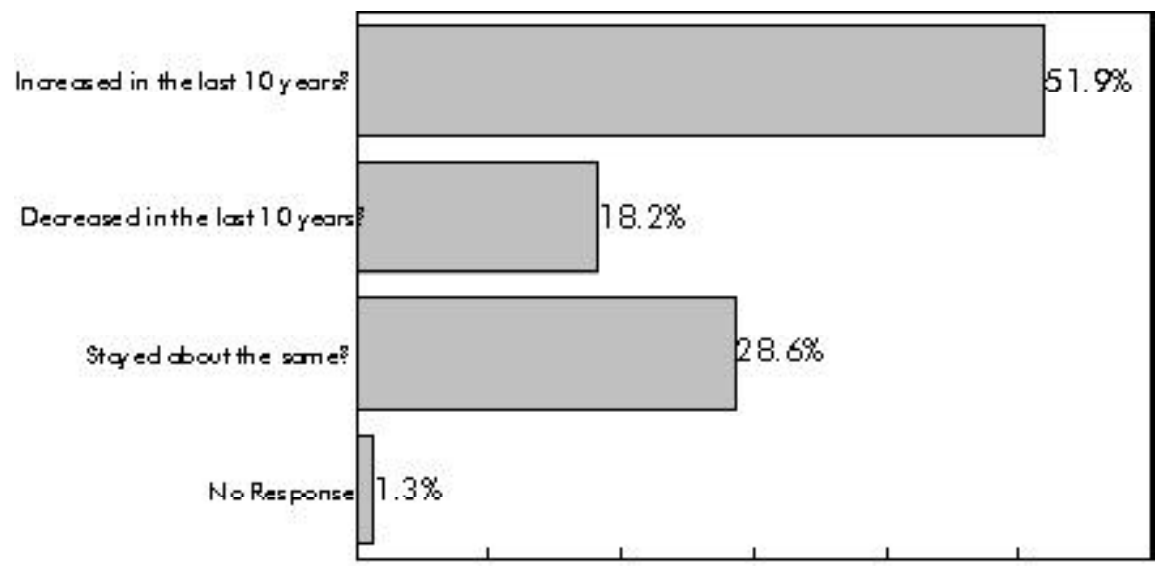

Figure 10

In comparison with other industries, do you think that the percentage of minorities and women in the transit industry is...

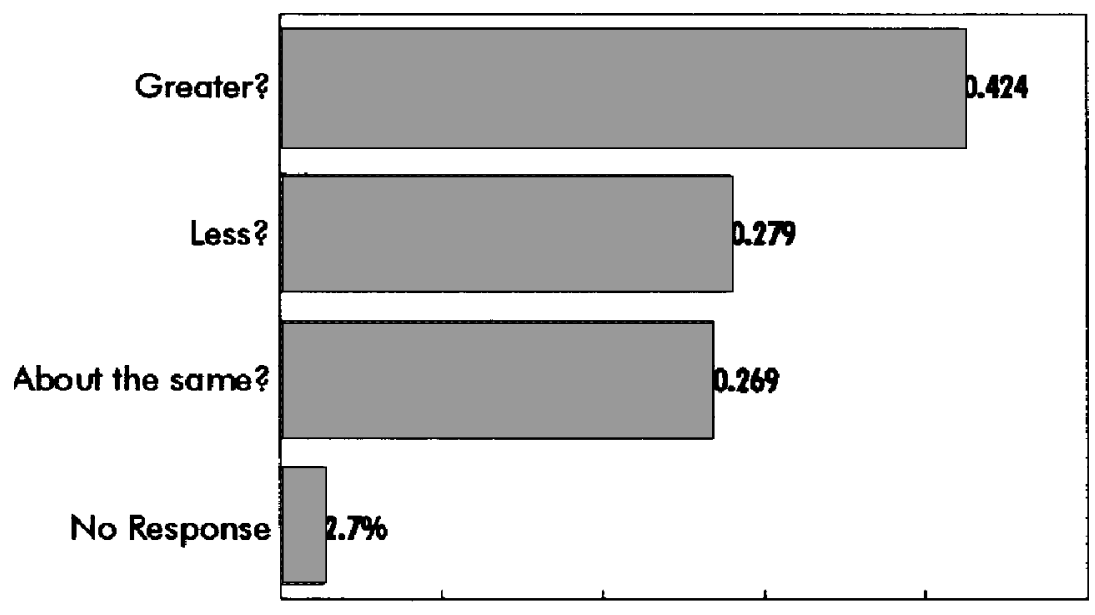

Respondents then were asked if they felt that they were victims of discrimination through various policies and programs at their agencies. This included areas such as the selection for assignments, promotions, mentoring, training, or being included in the flow of information. Interestingly, 70 percent of the respondents said their agencies did not provide a career guidance or mentoring program. Approximately 77 percent of the respondents said they did not receive any career guidance or mentoring from a supervisor or senior-level person in their agencies. Seventeen percent of these respondents said this was primarily due to their gender. Eighty-seven percent of all respondents said their agencies provided mechanisms to facilitate communications. However, slightly more than half the respondents, 52.9 percent, said they were not fully included in the flow of information in their agencies. Almost 19 percent of these respondents stated that gender accounted for their exclusion. 


\section{Women s Travel Issues}

Respondents were asked, "Does your agency have a training or professional development program?" Seventy percent of the respondents said "Yes." Most respondents, 71 percent, said they had access to opportunities for training or professional development in their agencies. Of the respondents who stated, "No," almost 27 percent, 21 percent thought it was due to gender. Over half, 57 percent of respondents thought they had equitable opportunities to be involved in significant projects at their agencies. Only 40 percent of these respondents thought that they did not. Of these respondents, 24 percent believed that it was due to gender.

\section{Figure 11}

Do you receive career guidance or mentoring from a supervisor or senior-level person in your agency?

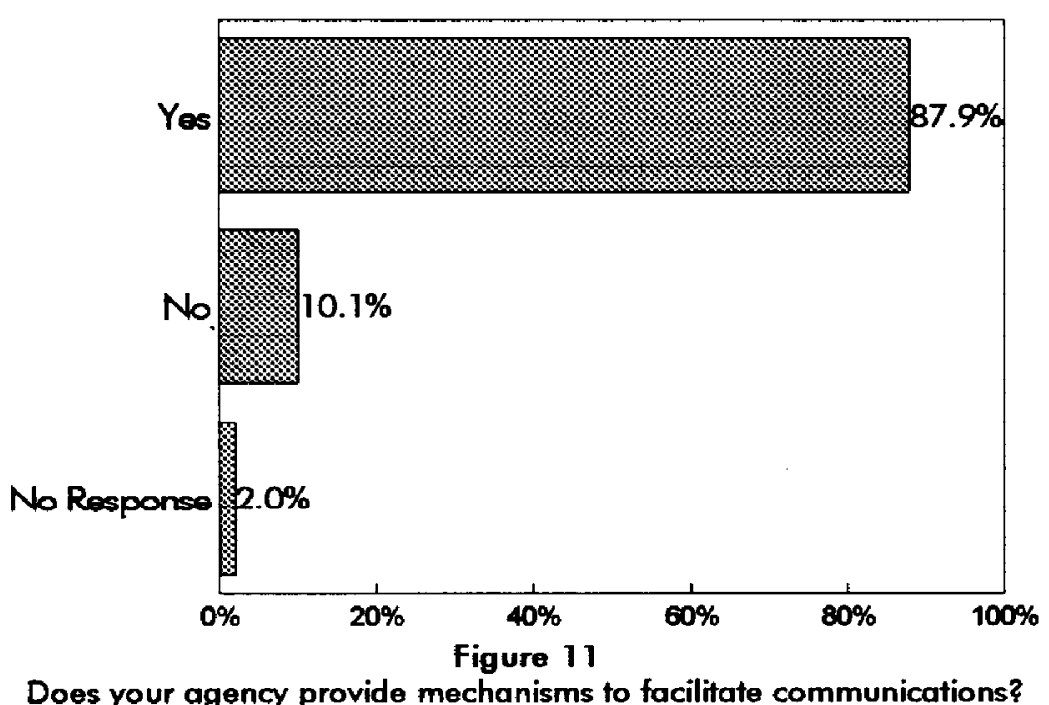

Figure 12

Does your agency provide mechanisms to facilitate communications?

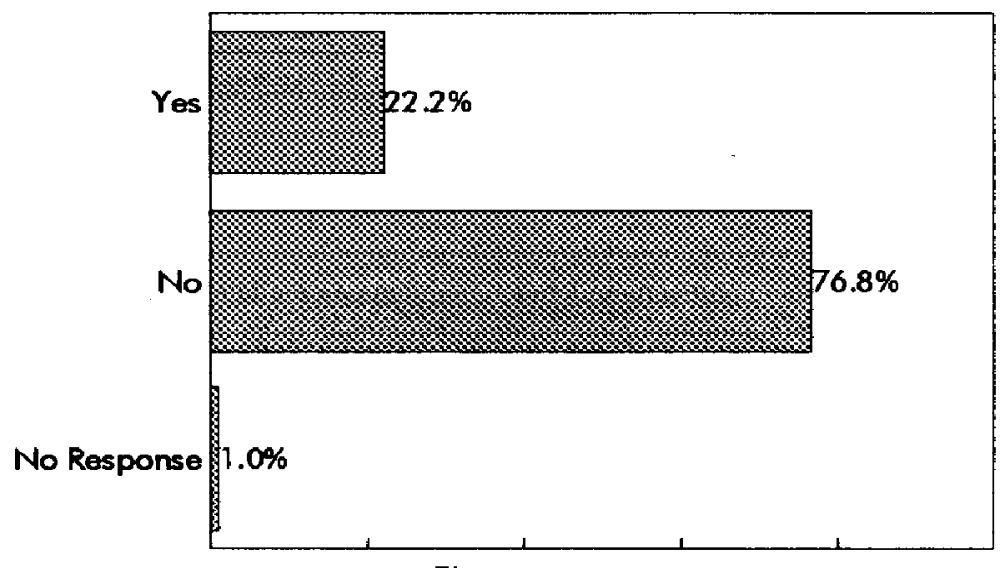




\section{Figure 13}

Do you think that you have equitable access to opportunities for training professional development in your agency?

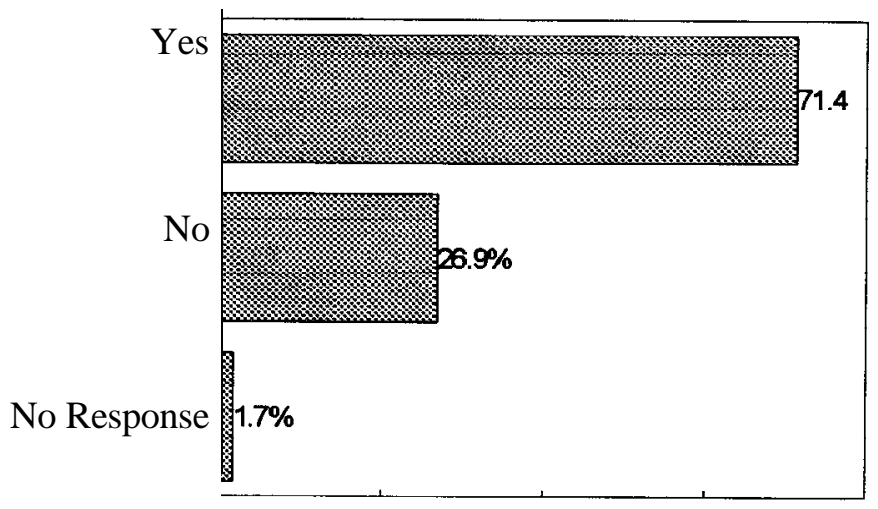

Regarding progress for minorities in transit, most respondents, 67.3 percent, said their agencies did not have a written career path or promotion guidelines. Most of the respondents, however, did think that their agencies are fair in providing salary increases and promotions. Approximately 45 percent of respondents stated that they have been unfairly denied a salary increase or promotion in their agencies. Of these respondents, nearly 35 percent said this was primarily due to gender. Interestingly, over two-thirds of respondents, 79.5 percent thought there were salary disparities at their agencies. Of this group, 41 percent thought the disparities were due to gender.

Figure 14

Do you think that you have equitable opportunities to be involved in significant protracts in your agency?

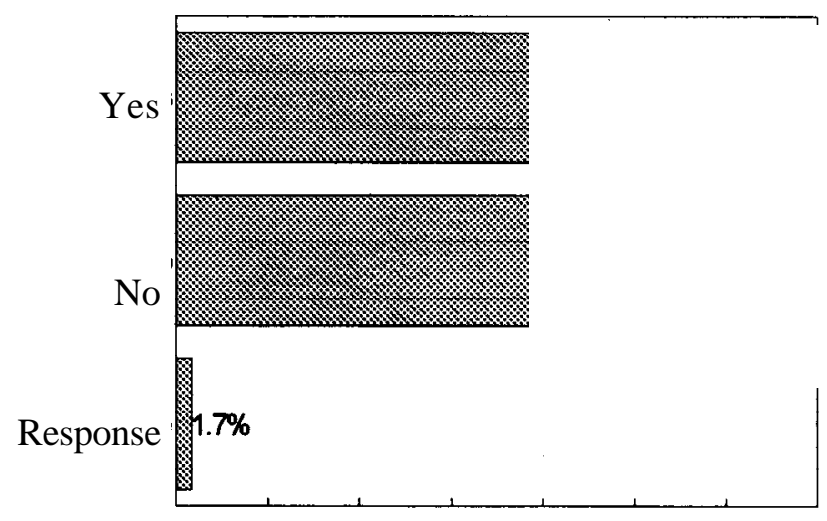


Figure 15

Do you think that you are fully included in the information of your agency?

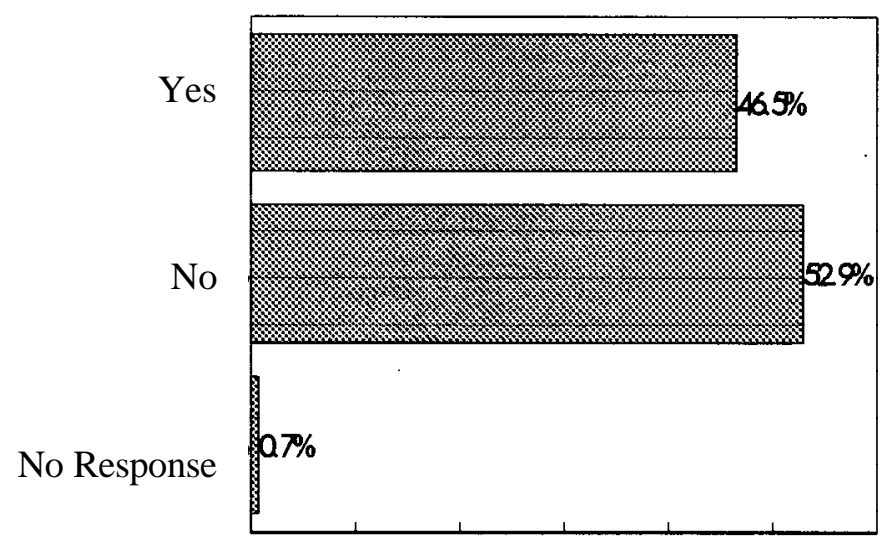

Figure 16

Does your agency have a training and professional development program?

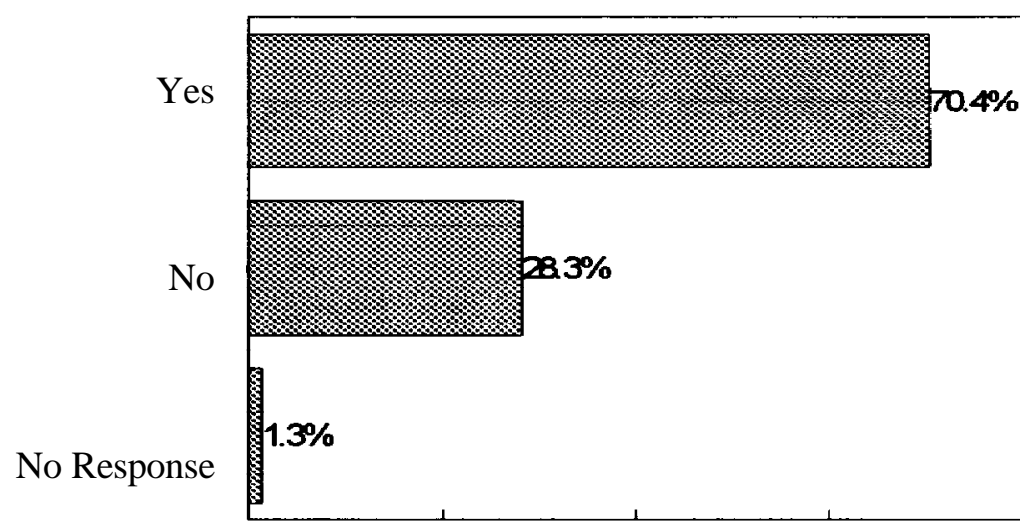

When asked to compare their experience, credentials, and training to their positions, 68 percent of respondents said their current jobs were commensurate with their backgrounds. Twenty-nine percent said they were in dead-end or support positions that were not equal to their skills and training. Of these respondents, 36 percent said that it was due to gender. Particularly in light of the recent debate over affirmative action, respondents were asked their opinions on affirmative action policies and if they were hired or promoted due these policies. Most of the respondents, 91.6 percent, think that affirmative action policies are important in advancing the interests of minorities and women in transportation. Respondents almost were evenly divided whether their hiring or promotions were due to affirmative action. 


\section{Figure 17}

Do you think that there are salary disparities within your agency?

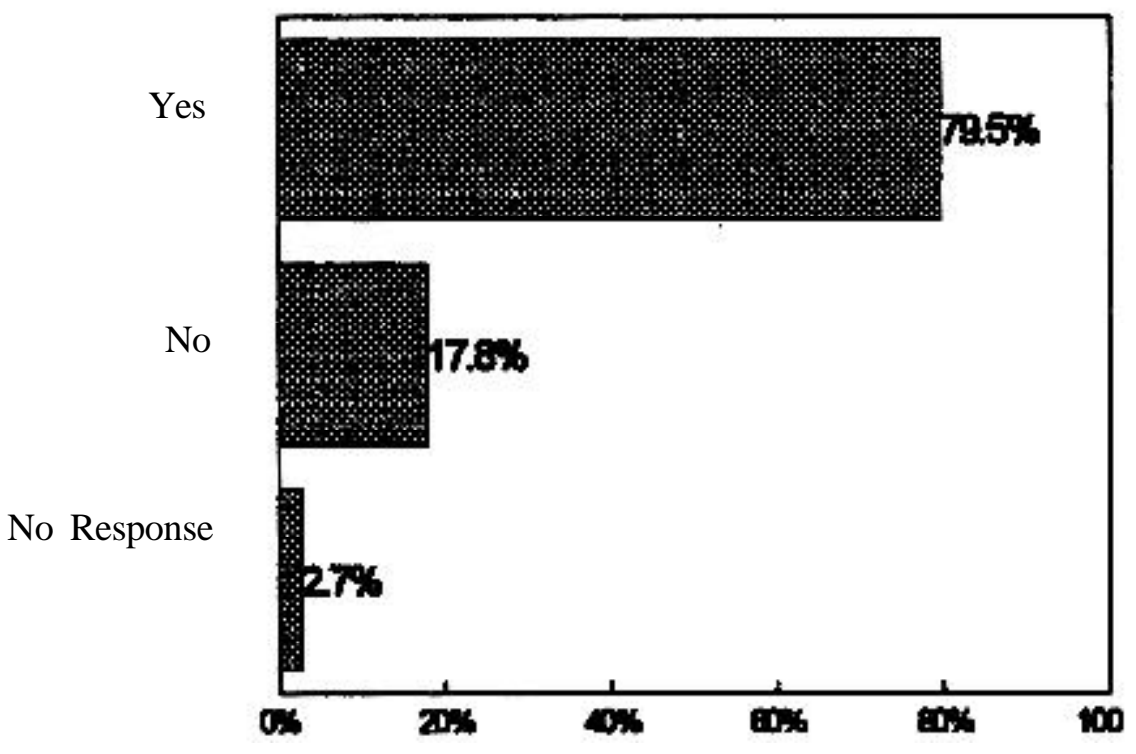

Figure 18

Do you think that you have been unfairly denied a salary increase(s) or promotion(s) in your agency?

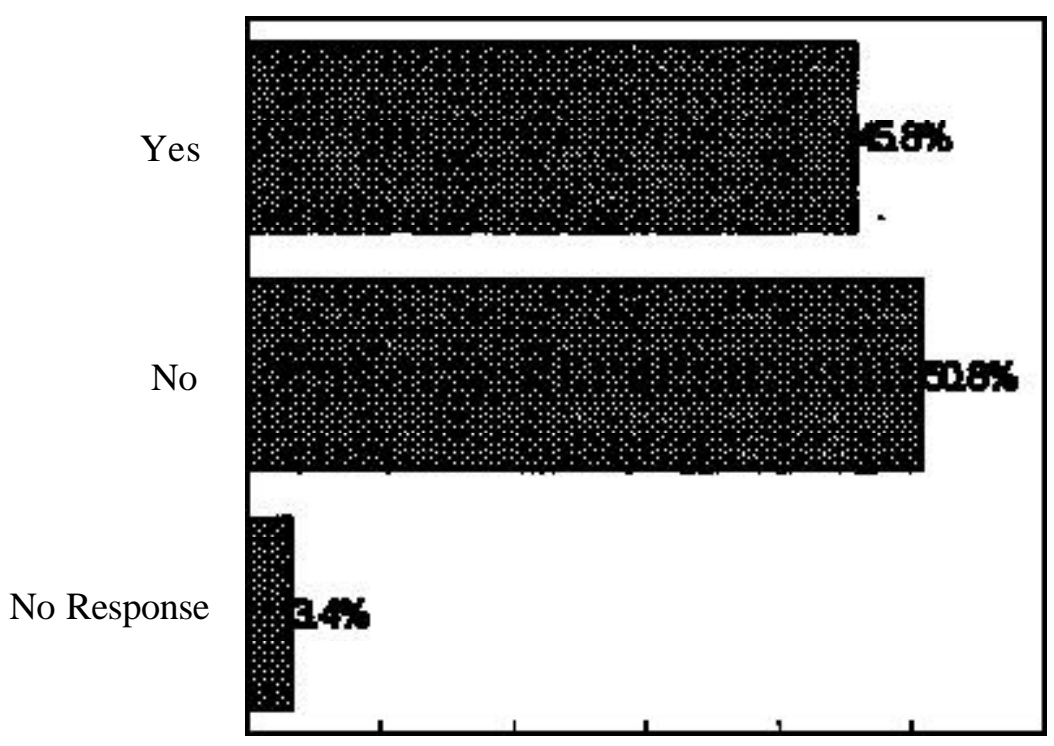




\section{Figure 19}

Does your agency have written career path or promotion guidelines?

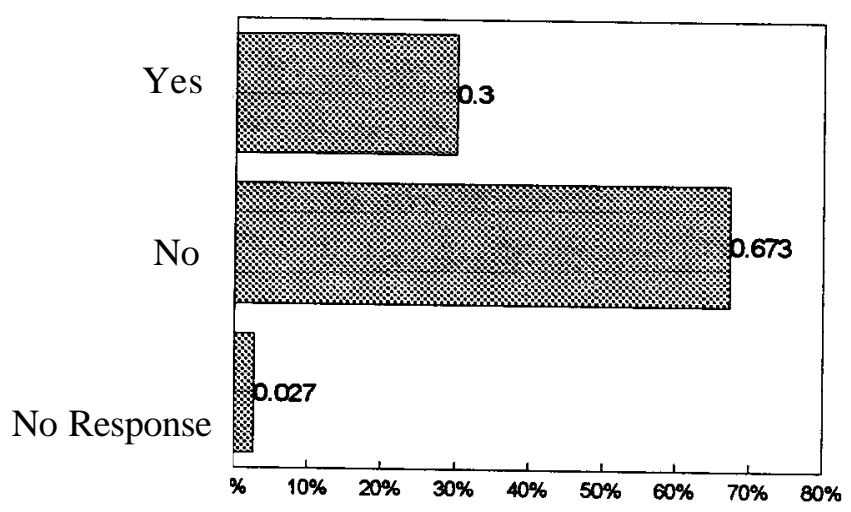

When asked to compare their experience, credentials, and training to their positions, 68 percent of respondents said their current jobs were commensurate with their backgrounds. Twenty-nine percent said they were in dead-end or support positions that were not equal to their skills and training. Of these respondents, 36 percent said that it was due to gender. Particularly in light of the recent debate over affirmative action, respondents were asked their opinions on affirmative action policies and if they were hired or promoted due these policies. Most of the respondents, 91.6 percent, think that affirmative action policies are important in advancing the interests of minorities and women in transportation. Respondents almost were evenly divided whether their hiring or promotions were due to affirmative action.

\section{Figure 20}

Do you think that affirmative action policies are important in advancing the interests of minorities and women in transportation?

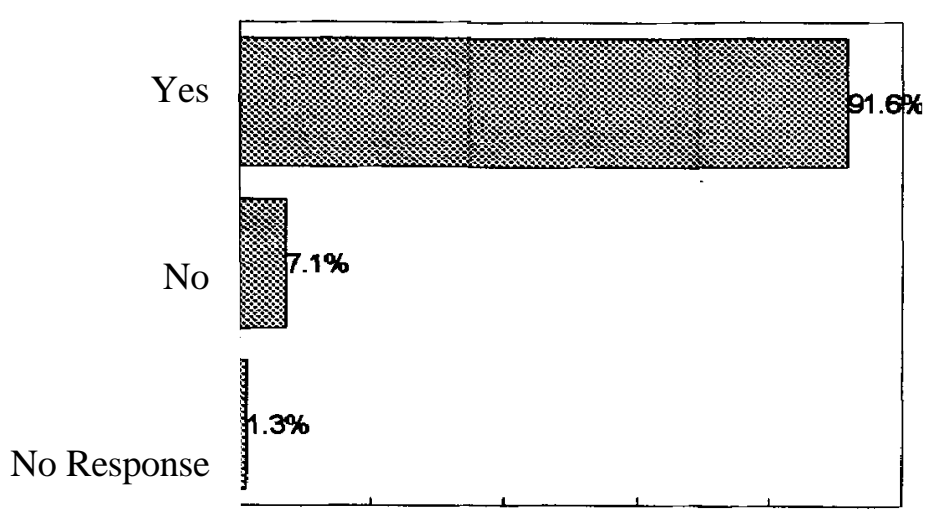


Women in Transit

B. Ward and E. Hill

\section{Figure 21}

Do you think you have been placed in a dead-end or support position that is not commensurate with your training or experience?

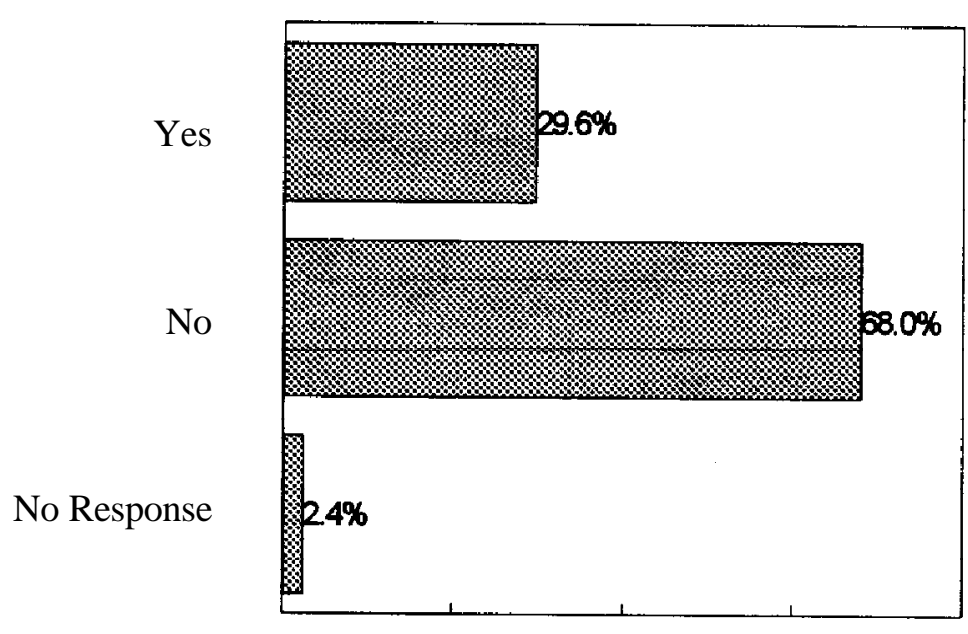

Figure 22

Do you think that you were hired or promoted, in part, due to affirmative action policies or plans in your agency?

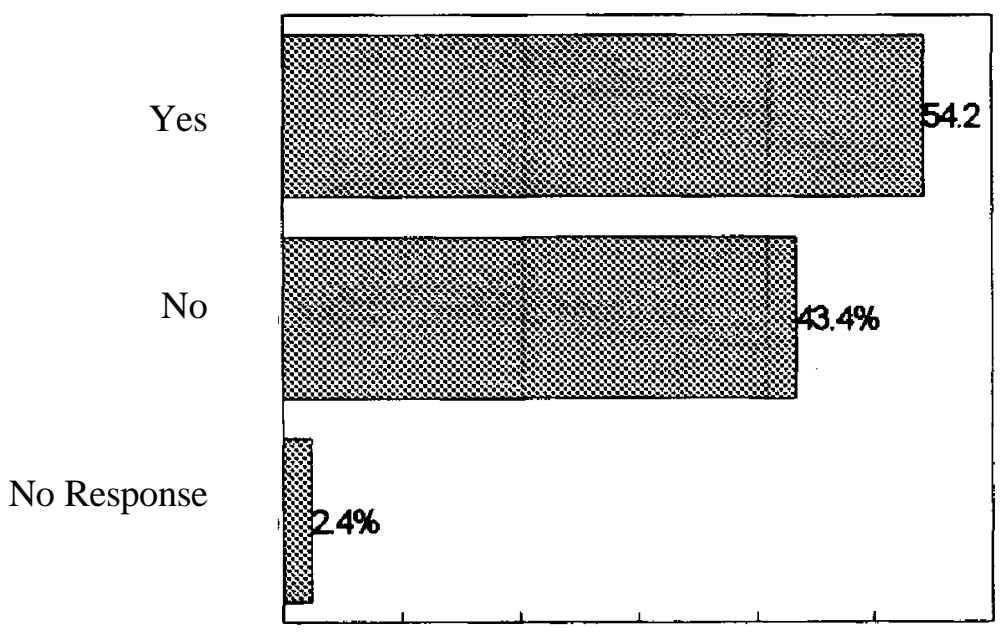


Respondents' salaries were compared by gender. The data show that most female and male respondents fell within the $\$ 40,000$ to 74,999 salary range. The median salary for female respondents was $\$ 57,600$; male respondents, $\$ 60,000$. The largest share of female respondents, 12.8 percent, was in the $\$ 40,000$ to $\$ 44,999$ range. The largest share of male respondents 14.8 percent was in the $\$ 50,000$ to $\$ 54,999$ range. This may suggest some disparities in salary based on gender for the sample.

Figure 23

Salary Distribution by Gender
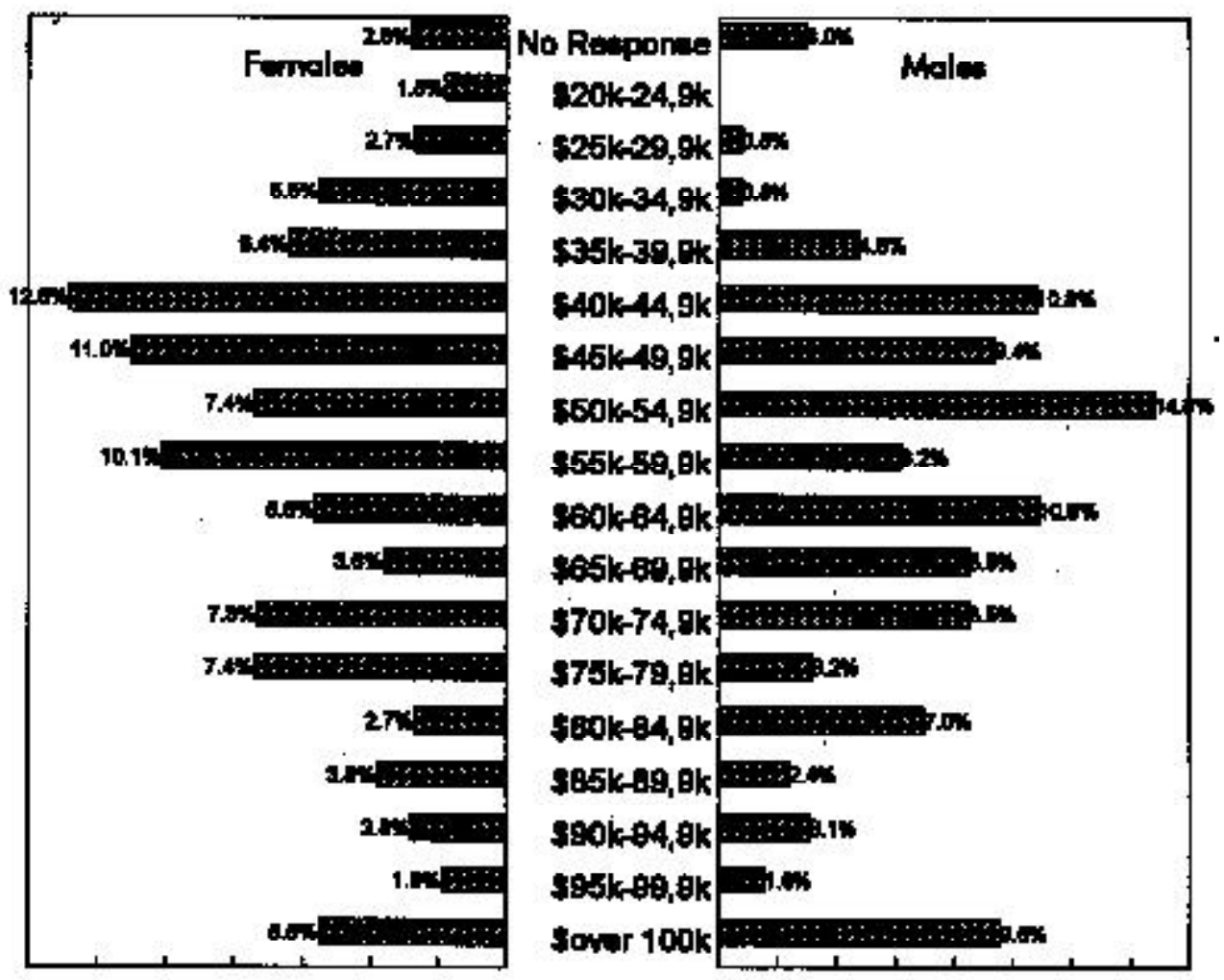

Regarding the relationship between salary and race and ethnicity, the median salaries for whites was $\$ 66,000$; minorities, $\$ 58,000$. The largest share of minority respondents, 12.8 percent, was in the $\$ 40,000$ to $\$ 44,999$ range. The largest share of white respondents 17.1 percent was in the $\$ 65,000$ to $\$ 69,999$ range. The difference between the median incomes of whites and minorities seem to suggest that gender and race or ethnicity are strong detriments of salary. This interpretation is consistent with the findings of the American Planning Association (1992:32). 
Figure 24

Salary Distribution by Race/ Ethnicity
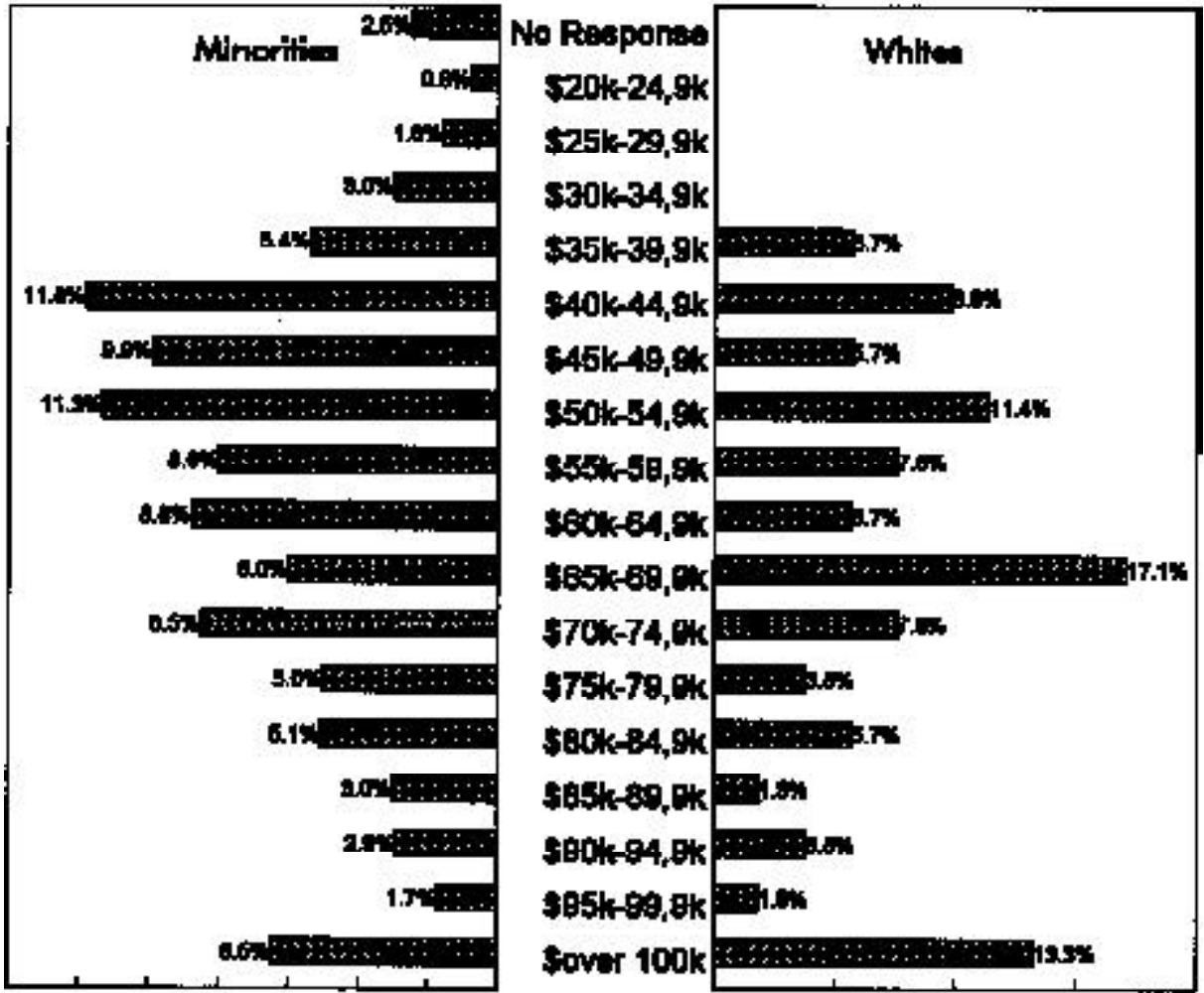

\section{SUMMARY}

The survey provided information on salary, experience, and social equity perceptions of minorities and women who work in the transit industry. The median age reported by respondents was 45 years, the median salary reported was $\$ 62,671$, and 42 percent said they had a master's degree.

Over half the respondents believe that the percentage of minorities and women in senior or management positions in the transit industry and at their agencies, has increased during the past 10 years. In addition, various questions were asked of respondents to assess if they had experienced discrimination through policies and programs at their agencies. Many respondents said that their agencies did not provide any career guidance or a mentoring program and that they did not receive any guidance or mentoring from a supervisor or senior-level person. A significant share of respondents said that their agencies provided mechanisms to facilitate communications and have training or professional development programs. However, approximately 53 percent said they were not fully included in the flow of information in their agencies; 26 percent said they did not have an opportunity for training and development in their agencies.

Most of the respondents, 67.3 percent, said their agencies did not have a written career path or promotion guidelines. Almost half the respondents, however, thought that they had been unfairly denied a salary increase or promotion in their agencies. A significant share of respondents said there are salary disparities 
at their agencies. Finally, most respondents, 91.6 percent, think affirmative action policies are important in advancing the interests of minorities and women in transportation.

\section{CHANGES IN TRANSIT LABOR SUPPLY AND SERVICE DEMAND FROM 1970 THROUGH 1990}

This section discusses some factors that have contributed to the increasing share of minorities in transit since the Jeffress study, such as the demographic changes in the workforce. It also presents interpretations of how socioeconomic changes have affected travel behavior and transportation demand. Occasionally these factors have increased the need for transit service and, in other instances, they have reduced service demand. These factors are presented to understand their effect on employment in an industry in which minorities and women have made significant progress.

\section{Demographic Changes in Transit Workforce}

Jeffress noted that African-Americans made significant gains in the transit industry during the labor shortages of World War II; this progress continued in subsequent decades in spite of falling demand for labor. Examining such factors as the image of the industry, industrial locations, the availability of other jobs for whites, and government action, may provide explanations for increased employment of minorities and women. ${ }^{31}$ The earlier sections have shown that in addition to the employment progress made by African-Americans, other minorities and women are showing higher participation rates. The factors presented by Jeffress may not only explain the changing workforce in transit, but also may explain the overall changing workforce in the United States.

Table 13 shows the total number of the civilian non-institutionalized population age 16 and over and the approximate participation rate for the total U.S. population for 1970, 1980, and 1990. Participation rates provide an estimate of the U.S. workforce. ${ }^{32}$ Data show that the participation rate has increased from 1970 to 1990 . Thus, it appears safe to assume an increasing workforce.

Table 13

U.S. Workforce for 1970, 1980, and 1990

\begin{tabular}{|l|ll|}
\hline \hline Year & Total Civilian Population & Participation Rate (Percent) \\
\hline $\mathbf{1 9 7 0}$ & 82.0 & 58.2 \\
$\mathbf{1 9 8 0}$ & 106.0 & 62.0 \\
$\mathbf{1 9 9 0}$ & 125.1 & 65.3 \\
\hline
\end{tabular}

Source: U.S. Census. 1980 General Social and Economic Characteristics, Table 86 Labor Force Status by Sex and Race: 1940 to 1980. 1990 General Social and Economic Characteristics, Table 44 Labor Force Characteristics by Race and Hispanic Origin: 1990.

Table 14 shows the proportionate minority and women's representation of the total workforce populace from 1970 to 1990. These data reflect important phenomena in American society, the participation rate growth of minorities and women in the workforce. During the last four decades, but especially since the 1970s, the overall labor force participation rate of women has increased substantially. In 1970, approximately 36.3 percent of all women were in the paid labor force; 1980, 42.1 percent of women were employed; and in 1990, 45.3 percent. In addition, the overall growth of minority participation in the labor force grew from 13.4 percent in 1970 to 18.0 in 1980 . The share of minority participation declined in 1990 to 17.9 percent. It should be noted the 1990 census separately counted the Hispanic population which included 8.1 percent of the labor force. 
of minority participation declined in 1990 to 17.9 percent. It should be noted the 1990 census separately Ideally, each cohort should have the same proportion of the workforce population as their respective population representations. For example, as the African-American population represented 10.7 percent of the 1990 workforce population, 10.7 percent African-American representation would be expected in the transit industry. (Data on ethnic/ race and gender cohorts for transit are presented in Tables 2.) This information is compared with data on gender and minority cohorts for the overall workforce in Figure 24. The comparison suggests that although the share of each minority cohort in the workforce has increased between 1970 and 1990, except African-Americans, each cohort have maintained a proportionate share of transit employment that is less than represented in the workforce.

The data also suggest that while demographic changes in the workforce are factors that have increased the propensity of minorities and women to enter the transit industry during the past decades, the changes have not had any dramatic impact on employee profiles in this industry; however, African-Americans have continued their progress. Additionally, census data show that America is becoming increasingly urbanized. The percentage of the population in urban areas has steadily expanded from 73.6 percent in 1970 to 73.7 percent in 1980 to 75.2 percent in 1990. Jeffress posited that transit systems are by definition, urbanoriented and located, with an available workforce that mostly consist of minorities, another factor contributing to a large minority labor pool for transit.

Table 14

Percent of Total Workforce by Race 1970 to 1990

\begin{tabular}{|l|lll|}
\hline \hline $\begin{array}{l}\text { Ethnicity/Race } \\
\text { and Gender }\end{array}$ & $\mathbf{1 9 7 0}$ & $\mathbf{1 9 8 0}$ & $\mathbf{1 9 9 0}$ \\
\hline White & 86.6 & 81.9 & 82.1 \\
Minorities & 13.4 & 18 & 26 \\
Women & 36.3 & 42.1 & 45.3 \\
\hline
\end{tabular}

Source: U.S. Census. 1980 General Social and Economic Characteristics, Table 86 Labor Force Status by Sex and Race: 1940 to 1980. 1990 General Social and Economic Characteristics Table 44 Labor Force Characteristics by Race and Hispanic Origin: 1990.

These changes in the workforce are projected to continue into the next century. According to the BLS, women will make up about 48 percent of workers by the year 2005 and minorities and immigrants will hold about 28 percent of all jobs, up from 26 percent in 1990. White men are expected to account for only 33 percent of those entering workforce by $2005 .{ }^{33}$ Additionally, "baby-boomers" who are mostly white and entered the labor force between 1970 and 1980, will start to reach 65 years of age around the year 2010; many of these workers will retire before 65. A significant share of labor will be replaced by immigrant populations. Approximately seven million people of the added population in the 1980s. were from net immigration. A disproportionate share of these new entrants was between 15 and 35 years of age, the age cohorts that make up most of the labor force. In view of the recent federal immigration legislation, which puts emphasis on skills as a criterion for entry, immigrates will have significant representation in needed skill areas. Consequently, it may be expected that minorities and immigrants may provide the flexibility for meeting future labor requirements and comprising a significant share of the workforce for the transit industry.

\section{Socioeconomic Changes in Society}

While the demographic changes in society over the past three decades have affected transit's workforce, changes in socioeconomic conditions during this period also have influenced travel behavior. These changes include modal share trends, increasing automobile use, and suburbanization. Each of these factors has 
employment in transit will be affected. While these changes have increased since Jeffress completed his study, public policy and a changing workforce seemed to have helped transit to maintain a position of stable employment. However, recent funding constraints and society's demand for better accountability of public funds may increase the pressures for transit officials to be better stewards of resources that support transit.

\section{Modal Share Trends and Automobile Use}

Census data show that between 1970 and 1990 there has been a decline in nearly all alternatives to single occupant vehicle (SOV) rates (i.e., carpooling, walking to work, and transit). Collectively, the growth and dispersal of population, employment in the suburbs, coupled with increases in income and auto ownership, have created an explosion in trips made by private vehicles for all trip purposes, including the home-to-work trip, the traditional market for transit. ${ }^{34}$ However, one category that may have possible growth in absolute terms is the working-at-home phenomenon. This upturn has long been predicted based on expectations for new computer-oriented opportunities. ${ }^{35}$

These trends may have negative influences on minorities' and women's employment in the transit industry. Increases in auto use may reduce the share of trips by transit, demand for service and the ability for transit to general revenue to support a growing labor force. Transit systems may have been compelled to increase fares to make up for the revenue lost from a declining market share or reduced service and labor force. Fare increases can provide limited relief to a revenue shortfall but only in the short-term. At some point fare increases are counterproductive because they may result in ridership losses so large that revenues decline, rather than increase. Additionally, reducing the labor force to operate transit service to recover any significant cost may be unsuccessful since union agreements and political forces may have prevented recovery from occurring.

Data presented in this paper suggest that minorities and women have enjoyed steady employment in the transit industry during the past three decades. Concerns about a declining market share and the possible impact on employment, implies a need to shrink the size of some transit systems, and, subsequently, employment opportunities for minorities and women.

An example of the effect that a declining market share may have on an industry is provided by the MetroDade Transit Agency (MDTA) in Miami, Florida. To mitigate the expenses that MDTA imposes on the budget, the county is planning to eliminate lower level jobs, many of which are in the Metro-Dade Transit Agency. More than 51 percent of the agency's 2,672 employees are black. While the costs associated with MDTA service include expenses other than the deficit caused by a declining ridership, an increase in or stable ridership may have averted the elimination of jobs.

A more recent example of how ridership declines and fare increases can affect employment opportunities in transit is provided by the Hillsborough Area Regional Transit Authority (HARTline), in Tampa, Florida. Ridership for the system declined after the board of directors voted to raise fares. In response to this, the board also approved a hiring and wage freeze for the agency, thus eliminating possible job opportunities for minorities and women. 
Travel is what economists call a "derived need." That is, people travel to do or consume something else. Therefore, transit's success is closely tied to the way residential, economic, and social activities are arranged on the landscape -- "land use." ${ }^{36}$ Hence, suburbanization may be another factor affecting travel behavior and the demand for transit service. Initially, suburbs developed as bedroom communities for workers with jobs in urban centers. During the past few decades, the character of suburbs has changed dramatically. Suburbs have become multifunctional centers including residential, employment, business, and institutional activities. ${ }^{37}$ Between 1970 and 1990, the proportion of the American population residing in suburbs grew from approximately 27 percent to 32 percent, an increase of about 31 percent. In response to the needs of suburbia, several transit systems have expanded their service area, thus, becoming regional authorities. This has allowed many transit agencies to increase financial and political support for their service. As a result, the power to affect policy decisions and assert political control has expanded from urban areas to suburban or rural communities by the appointment of additional board members. With the authority to influence decisions on employment and service, the composition of these new boards may have influenced on the opportunities for minorities and women in transit.

During the 1995 African-American Mobility Symposium, Wade Lawson, South Jersey Transportation Authority, presented the following observations about this occurrence and the effect on the progress by minorities and women in public transit to decline. ${ }^{38}$

- Regional transit boards may approach issues regionally as opposed to the impact on an urban community; the ability of a local mayor or community to affect policy decisions are reduced.

- There is a lack of minority control in the appointive process and a reduction of appointed positions available to elected officials that are minorities.

- Board members that represent majority communities may be insensitive to the travel demands of minority communities.

- The selection of executive level positions by new board members may exclude qualified minority and women candidates, perpetuating the "Good Old Boy" system.

Figure 25

Trends in Suburban Population

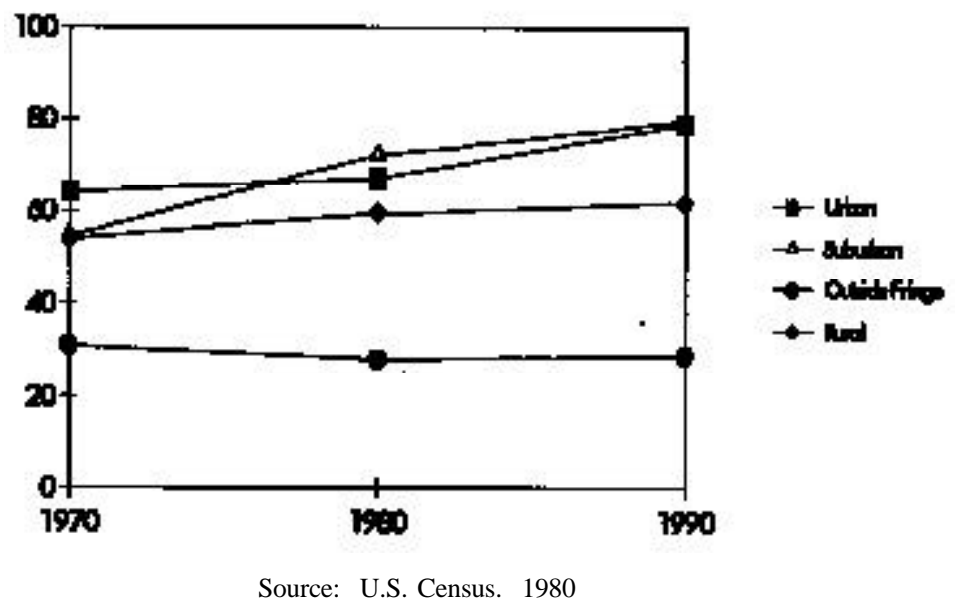




\section{PUBLIC POLICY EFFECTS ON AFRICAN-AMERICANS, OTHER MINORITIES, AND WOMEN EMPLOYMENT IN TRANSIT}

The Negro in the Transit Urban Transit Industry discussed the critical role that government policy has had in determining gender and racial policies in the transit industry. Civil service rules, state laws, federal grant regulations, and federal laws have had important impacts on employment decisions in transit and other public sector industries. Since the Jeffress study, several public policy initiatives have affected transit. The 1970s were especially important considering impacts of Title VII of the Civil Rights Act of 1964 were beginning to be reported and documented. Policy initiatives that also have had influences on transit include the FTA Policy on Private Participation, Clean Air Act Amendments, the Americans with Disabilities Act, and the ISTEA of 1991. A review of these regulations is presented in this section and is offered as a premise for understanding the relationship between public policy and employment opportunities for minorities and women in transit. Legal decisions that have affected affirmative action efforts to enhance minorities in transit also are presented.

\section{TITLE VII OF THE CIVIL RIGHTS ACT 1964}

The 1964 Civil Rights Act and later amendments officially prohibited racial discrimination in employment. The legislation was enacted before Jeffress's study and has had a significant role in breaking down barriers to the participation and advancement of minorities and women in the American workforce, especially white collar occupations. Further promoting equal employment opportunities for American workers, Congress passed the Equal Employment Opportunity Act of 1972. This extended Title VII coverage to state, local, and federal governments and gave the Equal Employment Opportunity Commission (EEOC) additional enforcement powers. For a time, the EEOC was rather effective in removing employment discrimination practices. Under the Reagan and Bush administrations in the 1980s. and 1990s, the number of broad, institutionally focused investigations of discrimination conducted by the agency declined sharply. Research suggests that an impetus for this decline was the appointment of conservative justices to the Supreme Court. As a result, several restrictive decisions were handed down which made it more difficult for workers to file, and subsequently, win discrimination suits. ${ }^{39}$ Two conclusions can be drawn from this review of the Civil Rights Act of 1964 and the 1972 amendment:

1. The law provided additional help to minorities in gaining and retaining employment opportunities. This is especially true for the transit industry; and

2. While progress was made by minorities and women in transit, the restrictions placed on filing discrimination claims by the Supreme Court during the Reagan and Bush administrations may have suppressed the possible entrance of additional minorities and women into transit management positions during the 1980s.

Without the assurance of the provisions in the Rights Act, some minorities may have been discouraged from filing discrimination claims, especially a claim involving the selection of a candidate for a management position.

The analysis of data in Tables 2 and 3 showed a decline in the proportion of minorities and women in the transit industry between 1980 and 1990, which is a significant change in the progress by minorities during the previous decades. In 1980 and 1990, the EEOC reported 121,558 job discrimination charges or claims filed the agency. Only charges based on race, sex or nation of origin were included. By 1990 the number of job discrimination charges had declined to 54,171, a reduction of approximately 55 percent. The influence of the Supreme Court's conservative views on ruling job discrimination suits is 
provided in Hill v. Metropolitan Atlanta Rapid Transit Authority (MARTA). African-American applicants for the job of bus operator at MARTA attempted to use statistical evidence in support of their race discrimination claim. The statistics showed that at a certain stage of the hiring process, AfricanAmerican applicants were discriminated against. Although direct evidence supported this inference, the lower court was unwilling to hold that discrimination at one stage meant that discrimination existed at another stage. ${ }^{40}$ The court further ruled that statistics alone are not proof of job discrimination, but MARTA was required to offer an explanation for the disparate handling of African-Americans applicants in the hiring process for bus operators.

Further illustrating the significance of the 1991 Act, in Wards Cove Packing Co. v. Atonio (109 S. Ct. 2115; 490 U.S. 642, 1989), a class of nonwhite workers sued two Alaskan salmon canneries under Title VII challenging hiring and promotion practices based on a disparate impact theory. Jobs at the cannery fell into two categories, cannery positions that were unskilled and non-cannery positions that were primarily skilled. The non-cannery jobs were predominantly filled by white workers and paid more than cannery jobs. Initially, the court hearing the case on appeal held that a showing of racial stratification by job category was sufficient to support a presumption of discrimination in hiring practices. Although the plaintiff had presented a statistical analysis of disparate impact, the case was returned to the district court to determine whether the employer had satisfied its burden of proving that any disparate impact was justified by business necessity. Before the district court could act, the case was acted on by the U.S. Supreme Court that subsequently reversed the case, making it harder for plaintiffs to prevail in a disparate impact case by shifting the burden of proof from the employer to the employees. The Supreme Court said that the plaintiffs must show more than just statistical proof of racial stratification of the workforce. Even if the plaintiff makes the proper statistical showing, Wards Cove requires a showing of causation by isolating and identifying the specific employment practices that are allegedly responsible for any observed disparities and showing that the specific practice did in fact cause the observed disparity.

The Civil Rights Act of 1991 is a direct congressional response to Wards Cove and other Supreme Court decisions that limit the scope of civil rights legislation in employment. ${ }^{41}$ The provisions in the Civil Rights Act of 1991 explicitly overturned the Wards Cove decision and returned to a standard for establishing a defense based on business necessity.

The Wards Cove Supreme Court decision implies that racial segregation in employment is still prevalent. It further depicts the attempt by a conservative court to eliminate statistical proof of racial stratification of the workforce from discrimination claims. The interpretation of the Rights Act by the Supreme Court, previously, had discouraged protected class members from filing lawsuits that may have impeded the advancement of minorities in the workforce.

The Act also established the bipartisan Glass Ceiling Commission. Its mandate was to identify the glass ceiling barriers that have blocked the advancement of minorities and women as well as the successful practices and policies that have led to the advancement of minority men and all women into management and decision-making positions. ${ }^{42}$ The Commission's report states the exclusion of members of groups, other than non-Hispanic males, in management positions as bad for business for various reasons, including changes in the demographics of the labor force and national consumer markets.

Data presented in this study show that minorities are approximately 28 percent of transit's workforce and almost half (48.7\%) of transit ridership in 1990. Additionally, the survey of the perception of transit 
employees showed that equally qualified minorities and women may be denied equal access to advancement into management because of gender, race, or ethnicity. Furthermore, as noted in the Glass Ceiling Report, it would appear that it is against the best interest of transit to exclude these workers from opportunities in management. Therefore, it is likely that the Civil Rights Act will continue to have positive impacts on minority employment and opportunities in management.

\section{FTA POLICY ON PRIVATE PARTICIPATION}

The FTA Policy on Private Participation (circa 1984) called for early involvement of private providers in the development of new transit services and for their maximum feasible participation in providing those services. ${ }^{43}{ }^{44}$ Dr. Jeffress's research concluded that public ownership aided African-Americans in getting equal opportunities for employment. While this Jeffress's conclusions may be true, mandating that private sector operators must be consulted in planning new or restructured services may have created additional employment and promotional opportunities for minorities in transit. On the other hand, the manner in which of private contracts are awarded may serve to limit opportunities for minorities and women. Congressman Alcee L. Hastings stated that 95 percent of the contracts let by Broward County (Florida) in 1995 were awarded to white males. Seventy-five percent of the remaining five percent were let to white females. ${ }^{45}$ Although the FTA privatization initiative in transit, particularly contracting out transit service which may have limited the abilities of most transit systems to expand, it provided the potential for job creation in another aspect - specialized markets. With changing transit markets, a federal budget crisis, and transit budget deficits, FTA believed that instead of competing for existing markets, more emphasis should be placed on specialized markets, including express commute, reverse commute, paratransit, regional service, and charter bus service. Effective use of the private sector could be made in these specialized markets.

As stated earlier, conventional transit markets have changed during the past three decades and new transit markets are emerging. As a result, an increasing number of trips are oriented from the central city to the suburbs and from suburb-to-suburb. Moreover, metropolitan travel requirements may have become too diverse and diffused to be served with a single uniform type of service. A significant portion of urban travel demand has become segmented into small market niches that The implications of continued contracting out of transit service as it relates to employment for minorities and women are significant. No matter how privatization is carried out, labor is affected. Contracting out previously directly-operated services may have two impacts on employment:

1. The demand for existing system labor may decline; or

2. Private sector labor demand in transit may increase.

While stagnating public transit labor growth, privatization could broaden the overall employment base of transit, thus providing opportunities forminorities and women in management positions and as private transitoperators.

\section{CLEAN AIR ACT AMENDMENTS}

The Clean Air Act Amendments of 1970 were established to reinforce the government's position to address environmental concerns that increased during the later part of the 1960s. This act created the Environmental Protection Agency (EPA) and empowered it to set ambient air quality standards. ${ }^{46}$ Under the act, the EPA was authorized to require states to formulate and implement plans to meet ambient air quality standards. This act emphasized changes in transportation systems for attaining air quality standards, including reductions in automobile use and increased transit use. 
The EPA was given broader control after the Clean Air Act Amendments of 1977 were adopted. The amendments increased the flexibility and local responsibility in the administration of the Act and required state and local governments to draft plans for meeting air quality standards in areas of non-attainment.

The 1990 Clean Air Act recast transportation planning in areas experiencing air quality problems. Such planning is to be geared toward improving air quality as well as mobility. Transportation planning also is mandated to conform with air quality planning. State and local officials are required to find ways to reduce emissions from the vehicle fleet, to develop projects and programs that will alter driving patterns to reduce the number of single-occupant vehicles and to make alternatives such as transit an increasingly important part of the transportation network.

These initiatives by the federal government to protect the environment put emphasis on reducing air pollution from mobile sources. Urban areas classified as "non-attainment areas" need to implement transportation control measures (TCMs) to reduce emission levels. The 1990 legislation also encouraged transit programs by requiring urban areas with severe ozone pollution to adopt specific TCMs to offset growth in vehicle miles traveled (VMT). The Clean Air Act Amendments of 1970, 1977, and 1990 have presented the transit industry with opportunities to expand its mode share, especially among commuters, increasing transit ridership, and expanding transit's labor force. Public policy programs of this nature are beneficial to the environment and the transit industry. An added benefit may be additional transit jobs for minorities and women.

\section{AMERICANS WITH DISABILITIES ACT}

The Americans with Disabilities Act of 1990 (ADA) prohibits discrimination based on disabilities in both the public and private sectors. In 1991, the U. S. Department of Transportation (USDOT) proposed regulations to carry out the ADA. A major feature of the new regulation was the requirement that any operator of a fixed route transit system provide paratransit or other special services to persons with disabilities. The paratransit service must be comparable to the level of service provided to individuals without disabilities who use the fixed route system. ${ }^{47}$

The ADA is a good example of the impact that public policy has had on transit because it is well documented. The USDOT estimated the average annual cost for providing paratransit service which ranges from $\$ 28.7$ million for the ten largest urban areas, $\$ 10$ million for areas more than one million in population to $\$ 750,00$ for areas less than 250,000 in population. ${ }^{48}$ Regarding the impact on employment in transit, Table 15 presents data compiled by APTA on operating employees for paratransit since 1990, the year that Congress passed the ADA. These data exclude administrative employees which are included in paratransit service. The data illustrate that between 1990 and 1994 employment related to paratransit service increased approximately 61 percent. This increase in jobs suggests additional management and professional opportunities for minorities and women who tend to be overrepresented among the users of paratransit services.

Table 15

Operating Employees for Paratransit between 1990 and 1994

\begin{tabular}{|c|c|}
\hline \hline Year & Employees \\
$\mathbf{1 9 9 0}$ & 22,740 \\
$\mathbf{1 9 9 1}$ & 24,196 \\
$\mathbf{1 9 9 2}$ & 25,863 \\
$\mathbf{1 9 9 3}$ & 30,021 \\
$\mathbf{1 9 9 4}$ & $36,802^{(\mathrm{P})}$ \\
\hline
\end{tabular}

$\mathbf{P}=$ Preliminary

Source: APTA 1996 Transit Fact Book 


\section{INTERMODAL TRANSPORTATION EFFICIENCY ACT OF 1991}

Signed into law in December 1991, the Intermodal Transportation Efficiency Act (ISTEA) provides authorization for highways, highway safety, and transit through fiscal year 1997. Total funding of more than $\$ 155$ billion was proposed over the six-year period. Additionally, the Act created a surface transportation program with flexible funding that provided new opportunities to address statewide and urban transportation problems.

Given the title a "jobs bill," ISTEA has been viewed as one of the quickest vehicles to stimulate economic activity in transit as well as outside the industry. An estimated four million jobs were expected to be created during period of authorization. The legislation presents several opportunities for inclusion of minorities and women to transit's workforce. An author of this landmark transportation bill, U.S. Representative Norman Mineta, stated "that full funding of ISTEA as a component of an economic package would offer stimulus benefits. Many ISTEA projects typically have relatively quick spend-out rates, such as highway resurfacing and rehabilitation projects, bus purchasing, transit rehabilitation, and transit operating assistance." 49

It is perhaps investments in transit that offer the greatest opportunity for continued progress by minorities and women in this industry. Federal grants to transit for capital construction and equipment, managerial training, technical studies, and demonstration projects may help to expand general employment in transit. This study has already suggested that transit has a history of concentrating service in urbanized areas where ridership is highest among minorities and women and provides most of transit's labor force. Since federal funding of transit projects will be focused on urban areas, it can be expected that minorities and women will bid for a significant share of any new jobs that may be created in transit is reasonable.

The total number of employees in transit in 1991, the year that ISTEA was signed into law, was 276,145. The most recent figures on transit employment, as reported in the 1996 APTA Transit Fact Book, show that in 1994, 311,573 workers were in the transit industry, an increase of approximately 13 percent over the number of workers in 1991. This serves as another indication of the impact that public policy may have on employment in an industry, especially when it involves federal assistance programs.

\section{POLICY DETERMINANTS AND THE FUTURE}

Minorities and women are important components of the transit industry and represent a dominant portion of the industry's workforce. Since Jeffress's study, other factors have influenced the increasing employment rates of minorities and women in transit. Jeffress noted that most minorities, mainly AfricanAmericans, made significant gains in the transit industry during the labor shortages of World War II. This phenomenon also was true for women. Other factors, such as, the image of transit, industry location, "white [male] flight" to other jobs, and government action also were impetuses for the progress by minorities and women. As noted earlier, public policy has continued to play a significant role in attracting minorities and women to transit as well as retention among these groups. Beyond the public policy initiatives during the past few decades, this study suggests that the changing demographics in the available workforce for transit, land-use policies, and the experience and level of skills of minorities and women are the factors that have affected their employment in transit.

Jeffress noted that African-Americans first became dominate in unskilled and semiskilled jobs and progressed into skilled positions. Although not as well reported, this scenario probably was similar for other minorities and women. As the survey of the perceptions of employees in transit suggests, many minorities 
and women are entering this industry in skilled positions with professional experience and advanced credentials. As a result of an expanding workforce, this trend in transit may continue in the future.

Significant changes have occurred in the transit industry Jeffress's study; additional changes are anticipated after this research. The ongoing debate over affirmative action rules and technology advances that will affect transit also will influence employment in the industry. Following are brief comments on these and other issues in transit and what the future may bring.

\section{AFFIRMATIVE ACTION}

Affirmative action has its roots in the Civil Rights Act of 1964. It was promoted as a mechanism to ensure that minorities and women were recruited by private and public sector employers and given opportunities to be hired and promoted. There have been many additions to the policy. During the Nixon administration, this policy incorporated a system of goals and timetables that provided guidelines for agencies and companies to follow. As discussed, affirmative action lost some gains during the 1980s. The Civil Rights Act of 1991 has helped to redress this matter and maintain affirmative action as a tool to level the playing field for minorities and women in the workplace.

In 1995, affirmative action programs suffered what may be another setback in the Adarand Contractors v. Peña ruling. Adarand Constructors, Inc., submitted the low bid to the prime contractor on a USDOT contact. The contract contained a subcontractor compensation clause, which gave the prime contractor a financial incentive to hire subcontractors certified as small businesses controlled by socially and economically disadvantaged individuals. Adarand did not meet this certification but filed suit, claiming that the race-based presumptions used in the subcontractor compensation clauses violates the equal protection component of the Fifth Amendment's Due Process Clause. The court held that federal laws and programs that use race-based preferences in minority business set-aside programs must meet a "strict scrutiny" standard to be found constitutional under the equal protection clause of the Fifth Amendment. In addition, this standard must meet a compelling government interest.

Partly because of conservative successes, like the Adarand ruling, Republican leaders are calling for a repeal of all gender and race-based federal affirmative action programs. In their view, affirmative action is nothing more than a quota or reverse discrimination system. As a first response to this, President Clinton declared his support for affirmative action programs and has initiated steps to reforming policies that create quotas, preferences, reverse discrimination, or that have achieved its purposes. Subsequently, the President has decided to suspend for at least three years federal programs that set aside contracts for minorities or women; but more specifically, that have race as a basis. Undoubtedly, any subsequent reviews of affirmative action policies will have a tremendous impact on the recruitment, hiring, and promotion of minorities and women in transit.

\section{INTELLIGENT TRANSPORTATION SYSTEMS}

Intelligent Transportation Systems (ITS) generally refers to projects that apply advance technologies to improve the efficiency and capacity of transportation systems. The transit component of ITS is called the Advanced Public Transportation Systems (APTS) which includes technologies as smart cards and buses, advanced vehicle location systems, and interactive video. Many similar technologies have already been applied by trucking firms and delivery services, i.e., Federal Express and UPS. Passage of ISTEA, with its emphasis on ITS, focused national attention on this emerging field. ISTEA brought more than exposure to ITS, authorizing $\$ 600$ million in appropriations over a six-year period. 
Most of the APTS products that will find their way into full deployment will target specific groups of people. For example, smart cards cannot be effective without the support of the urban minority community. As shown in this study, minorities and women have made significant progress in transit. Changes in transit's infrastructure threaten the industry's ability to retain the workforce in light of rapidly advancing technology. The problem relates to acquiring the skills necessary to adopt the latest in technology and keep pace with subsequent modifications. ${ }^{50}$ Just as in the construction days of the interstate system when inner city communities were physically divided by freeways, these technologies can become a major barrier in the industry workforce. ${ }^{51}$ Studies show that most of the ITS workforce will emanate from the classical engineering and applied science areas, where minorities and women are traditionally underrepresented. ${ }^{52}$ This suggests that management opportunities for these groups will be reduced in the future. Therefore, being prepared for the educational challenges and economic opportunities that APTS brings to the industry is important for minorities and women.

\section{FEDERAL ASSISTANCE}

As part of an overall effort to balance the federal budget, assistance to mass transit will be reduced during the balance of this decade and, perhaps, on into the future. Operating assistance will continue to be a target because the savings to the federal government are big and are typically spent quickly as opposed to capital funds that may be appropriated but are not spent for years.

In FY 1996, the federal transit appropriation was $\$ 4.6$ billion, $\$ 1.6$ billion for capital programs and $\$ 710$ million for operating programs. Congress is proposing a reduction of between 11 and 13 percent in appropriations for transit capital and operating programs. The most significant aspect of this proposal is a 44-percent reduction in operating grants. As stated previously, this funding strategy will compel transit operators to cut service and raise fares that may adversely affect ridership. The proposed reduction in operating assistance also will have an impact on employment. For example, with state and local matches, the current reductions in transit operating levels from FY 1995 are about $\$ 600$ million; this amount supports about 40,000 jobs each year. ${ }^{53}$ Again, as this research has suggested, transit agencies employ large numbers of minorities and women. The threat of further reductions in operating assistance could lead to more layoffs at transit systems. A survey completed by APTA showed that due to recent transit budget cuts, several transit agencies have laid off workers. Additionally, the cuts in federal assistance to transit will ultimately curtail plans to expand services in high growth areas that may also limit growth in transit employment.

However, similar to the effect of ISTEA had on employment in the industry, it is anticipated that ISTEA II will affect employment opportunities for minorities and women. The challenge for the transit industry in reauthorization will be to prove that past appropriations for capital and operating projects have reduced automobile use, improved air quality, mobility for the transit dependent, and affected Americans' daily lives in a positive way. As stated earlier, capital funds that may be appropriated but are not spent for years, leaving transit agencies with large unspent funding balances. Without having produced any projects at past funding levels, justifying increased levels for capital assistance that may support continued or additional employment may be difficult. 


\section{INSTITUTIONAL BARRIERS}

Besides developing affirmative action programs that will provide a true level playing field for all workers, other equal opportunity initiatives, which may be metamorphosed into public policy, will need to be established that will remove the institutional barriers to minorities' and women's progress. In spite of the legislative mandates to eradicate job discrimination, minorities and women still encounter interrelated institutional barriers that operate at the individual, group, and organizational level to limit their advancement.

At the individual level, African-Americans are faced with subtle racism and prejudice and are challenged with negative stereotypes about their suitability and competence for management responsibility. For women, the factors impeding career advancement have focused on their behavior and attitudes toward work and career commitments and human capital characteristics. This argument proposes that the competition between work and home responsibilities is justification for the lack of women in management positions. Additionally, lower educational attainment and choice of programs, such as humanities, are translated into a position with less responsibility. Factors identified as barriers to Asians and Hispanics include poor English language skills and unfamiliarity with the organizational culture. The literature is incomplete with information on the impediments to career advancements for Native Americans. On the group level, conflicts between cultures and exclusion from the formal and informal networks, create an environment that limits minorities' and women's progress. Additional constraints within the organizations that may significantly impede career developments include: less access to mentors; bias in rating of performance and promotion criteria; and shunting into positions that do not lead to senior leadership roles in organizations.

Increasingly, public and private organizations are recognizing the business case for overcoming institutional barriers, or breaking the "glass ceiling," that faces minorities and women. This is an appropriate attitude for the transit industry to have since their consumer base-transit passengers-is largely represented by these groups. While affirmative action and equal employment opportunity have been relatively effective in providing access to employment for minorities and women, policies and programs to enhance the retention and development and advancement of minorities and women in the transit industry must be a result of individual transit agency initiatives.

\section{AGENCY RESTRUCTURING: DOWNSIZING}

During the 1996 African-American Mobility Symposium, the keynote speaker, Congressman Alcee Hastings of Florida offered the following remark about structural change in organizations in America. "In the era of downsizing, right-sizing, outsourcing, reengineering and reinventing, what we want to know here is how minorities, in order to avoid retrogression to the point of oblivion and ignominious defeat must seek better formulae in a mathematical nonlinear regression-based allocation model to deal with intermodal bias and neglect. In other words, in order to keep from getting left out, we need more money." 54

The effects recent recessions and the efforts of Congress and the Administration to balance the federal budget through reduced spending, especially for transit, restructuring of transit agencies provides yet another opportunity for increased productivity. Complementing this scenario is the concept of giving more authority and responsibility for financial support for transit to local governments, who already are strapped in many cases to pay for essential public safety and human services. The idea of restructuring or downsizing transit agencies becomes even more appealing. 
Interestingly, some factors that are leading to corporate restructuring can be found in the transit industry. These include an increased need for flexibility to allow for quick responses to changing markets and new technology and changes in the political and economic climates. Information earlier discusses the impacts that transit's markets, such as suburban riders, reverse commuting, and technology may have on employment. Congress and state legislatures are conservative in their views on transit funding. The economic climate may affect the level of ridership if users choose between the affordability of cars and using transit.

Research findings on the effect of restructuring or "downsizing" on minorities and women in the private sector are mixed. The application of this business practice to the transit industry may render similar results. Some findings in a study entitled, The Impact of Corporate Restructuring and Downsizing on the Managerial Careers of Minorities and Women: Lessons Learned from Nine Corporations,${ }^{55}$ reveal the following:

- In more than half of the companies in the survey, white women and to somewhat lesser degrees minorities have increased their representation both in absolute numbers and in proportion to white men between 1990 and 1994. This has been the case, especially in companies that have increased their managerial force while restructuring. Among companies that downsized, examples of relatively more minorities and women were let go and examples more white men were let go (both in terms of absolute numbers and proportionately) exist. This suggests that it is not necessarily the case that whenever a company downsizes, proportionately more minority and female managers will lose their jobs.

- Companies in the survey reported losing ground in their efforts to maintain a diverse managerial force as the most likely scenario active steps were taken to maintain or increase the representation of minority and female managers.

- In absolute numbers, white male managers have absorbed the bulk of the layoffs, early retirements, and other forms of job severance during downsizing, but not necessarily in proportion to their representation in all of management. In large part, this is because there are many more white men in management than any other group. Companies simply do not have very many minority or female managers that would make a sizable impact on the magnitude of their managerial force.

This may suggest that if transit agencies considered restructuring or downsizing, white women would increase their share and number of management position. The absolute number of white men would decline, but not necessarily the proportion. However, minorities and women also may be at risk of losing management positions if the organization is not active in maintaining a diverse workforce.

While the transit industry is not becoming dominated by African-Americans, this research suggests that minorities and women, in general, are beginning to have a larger role in the transit industry at various levels. Data presented here suggest that, except Africa-Americans, minorities and women have maintained a proportion of transit employment that is less than represented in the workforce. Unfortunately, legislative mandates that were successful in advancing the role of minorities and women in transit during the past decades, may become less successful in the future. Witness the attack by on affirmative action programs. Political and industry leaders should continue their efforts to remedy the effects of past and current discrimination. These efforts could be in the form new legislation or modifications of existing affirmative action policies and programs. 
For minorities, and women to maintain the progress made in transit, they will need to become active in developing structures to achieve this goal. For example, taking an active role in networking with minorities and women in the industry, educational preparedness, and reengineering of skills provide opportunities for career advancement for minorities and women. These opportunities exist for African-Americans through the many transportation programs at Historically Black Colleges and Universities. Likewise, the industry can provide support to these initiatives. The industry and individual agencies must strive to remove barriers to advancement for minorities and women and identify opportunities to include these groups in senior level management positions. Suggested of initiatives include:

- establishing mentoring programs;

- supporting diversity at the highest management levels;

- providing diversity training;

- producing better monitoring and reporting of diversity goals and programs, such as EEO reports, affirmative action plans, and so on; and

- establishing career paths and promotion guidelines.

Attempts to eradicate disparate treatment based on race or gender should be an industry-wide objective for transit. If not, the industry stands to lose ground on its efforts to maintain a diverse managerial and labor force. 


\section{REFERENCES}

American Planning Association. Planners Salaries and Employment Trends, 1991. Planning Advisory Service Report Number 439 (October 1992).

American Public Transit Association. Americans in Transit: A Profile of Public Transit Passengers, Special Report (December 1992).

American Public Transit Association. 1991 Transit Fact Book (October 1991).

American Public Transit Association. 1996 Transit Fact Book (January 1996).

American Public Transit Association. Transit Funding Needs 1995-2004: Findings of an APTA Meeting Survey (May 1994).

Ayele, Moges. "Attracting Minorities to the Transportation Profession: Perspective of Historically Black Colleges and Universities." The Cable Journal, a publication of the Conference of Minority Transportation Officials (Winter 1994).

Biddle, Richard E. Wards Cove vs. Atonio. Redefines EEO Analyses, Personnel Journal; v.69, n6 (1990).

Burbridge, Lynn C. The Glass Ceiling in Different Sectors of the Economy: Differences Between Government, Non-profit, and For-profit Organizations. Wellesley College Center for Research on Women (June 1994).

Catalyst. Successful Initiatives for Breaking the Glass Ceiling to Upward Mobility for Minorities and Women (1993).

Conference of Minority Transportation Officials. Transit Budget Cuts. Cable Express, volume 27 (May/June 1996).

Cox, Taylor, Jr. and Smolinski, Carol. Managing Diversity and Glass Ceiling Initiatives as National Economic Imperatives. The University of Michigan. (January 1994).

Darity, William A., Jr. Racial Inequality in the Managerial Age: An Alternative Vision to the NRC Report, The National Research Council's Report on the Status of Black Americans, 1940-85; vol. 80, no. 2 (May 1990).

Department of Labor (1991) The Glass Ceiling Initiative, A Report; Department of Labor, Washington, DC.

Dougherty, Joe. Evolution of Federal Transit Policy. Passenger Transport 50th Anniversary Special Issue, American Public Transit Association (April 1993).

Edmondson Bell, Ella L.J. and Nkomon, Stella M. Barriers to Work Place Advancement Experienced by African-Americans, The Glass Ceiling Fact-Finding Report: "Good for Business: Making Full Use of the Nation's Human Capital." School of Industrial and Labor Relations Electronic Archive, Cornell University. (September 1994). 
Enty, Frank. Looking Ahead. The Cable Journal, Conference of Minority Transportation Officials (Spring 1994).

Feagin, Joe R., and Vera, Hernan. "White Racism,” Routledge Publishing (1995).

Hamlin, Nancy R.; Erkut, Sumru; and Fields, Jacqueline P. The Impact of Corporate Restructuring and Downsizing on the Managerial Careers of Minorities and Women: Lessons Learned from Nine Corporations. The Glass Ceiling Fact-Finding Report: "Good for Business: Making Full Use of the Nation's Human Capital.” School of Industrial and Labor Relations Electronic Archive, Cornell University (September 1994).

Harris, John F. Clinton Avows Support for Affirmative Action, The Washington Post, July 20, 1995; no. 227, A12.

Jeffress, Philip W. "The Negro in The Urban Transit Industry," Published by the Industrial Research Unit, Department of Industry, University of Pennsylvania (1970).

Jeffress, Philip W. Interview with Dr. Jeffress (September 1995).

Lawson, Wade. The Continuing Evolution of Public Transportation Policy, Proceedings of the African-American Mobility Symposium II (April 5-7, 1995).

Leonard, Jonathan S. Use of Enforcement Techniques in Eliminating the Glass Ceiling, Walter A. Haas School of Business, University of California (April 1994).

Padron, Manuel. Impacts of Changing Demographics on Transit Planning, Manuel Padron \& Associates (June 1993).

Pas, E I. The Effect of Selected Socio-demographic Characteristics on Daily Travel-Activity Behavior, Environment and Planning, vol. 16 (1984).

Pisarski, Alan E. Travel Demands in the 1990s, A Look at Demographic Changes that Will Affect Highway Transportation in this Decade. Annual meeting publication of The Highway Users Federation (November 1990).

Pikarsky, Milton and Johnson, Christine. American Transportation in Transition, Built Environment, vol. 8 no. 3 (1982).

Saka, Anthony A. Assessment of ITS Impacts in the Urban Minority Community. Proceedings of the 1995 Annual Meeting of ITS America, volume 2 (March 1995).

Schulz, David F. Can Transit Be Saved? ITI publication no. 12, (July 1992). 
Shaw, Lois B.; Champlin, D. P.; Hartmann, H. I.; and Spalter-Roth, R. M. The Impact of the Glass Ceiling and Structural Change on Minorities and Women, The Glass Ceiling FactFinding Report: "Good for Business: Making Full Use of the Nation's Human Capital." School of Industrial and Labor Relations Electronic Archive, Cornell University (December 1993).

Thomas, Roosevelt, et al. The Impact of Recruitment, Selection, Promotion and Compensation Policies and Practices on the Glass Ceiling. The American Institute for Managing Diversity, Inc., Morehouse College (April 1994).

Volinski, Joel. Notes from APTA Legislative Conference (March 1996).

Weiner, Edward. "Urban Transportation Planning in the United States, An Historical Overview," Praegers Publishers: Greenwood Press, Inc. (1987).

Wernick, Ellen D. Preparedness, Career Advancement, and the Glass Ceiling. Glass Ceiling Commission, U.S. Department of Labor. (May 1994).

Weyrich, Paul M. and Lind, William S. "Conservatives and Mass Transit: Is It Time for a New Look?” Study by Free Congress Foundation (1995).

Woody, Bette, and Weiss, Carol. Barriers to Work Place Advancement: The Experience of The White Female Work Force. William Monroe Trotter Institute, University of Massachusetts (April 1994).

Wulkan, Alan. "It's Not Too Late to Act on ISTEA II". METRO Magazine. Bobit Publishing Company (January/February 1996).

U. S. Bureau of the Census. Civilian Labor Force (1970, 1980, and 1990).

U. S. Department of Transportation, Federal Highway Administration. 1990 Nationwide Personal Transportation Survey, Travel Behavior Issues in the 90s (July 1992).

U. S. Department of Transportation, Federal Transit Administration. Impact of Transit Funding Cuts (1996).

U. S. Department of Transportation. Urban Transportation Planning in the United States, An Historical Overview. Revised Edition (November 1992). 


\section{NOTES}

${ }^{1}$ Philip W. Jeffress, The Negro in the Urban Transit Industry, (Industrial Research Unit, Department of Industry, Wharton School of Finance and Commerce, University of Pennsylvania, 1970), iii.

${ }^{2}$ Ibid. 101.

${ }^{3}$ American Public Transit Association, Transit Fact Book 1992, Table 96 Trend of Transit Employment, Compensation, and Labor Costs (APTA), 96.

${ }^{4}$ In the interest of cultural competence, African-American is used instead of "Negro" to describe people of African descent or people referred to as "black." "Other minorities" is used to describe people of Hispanic, Asian, Pacific Islander, Native American and Alaskan descent. Additionally, throughout this study the term "minority" is used to describe people other than white males and females.

${ }^{5}$ Jeffress, 96.

${ }^{6}$ Jeffress, 97.

${ }^{7}$ Ibid.

${ }^{8}$ Jeffress, 100.

${ }^{9}$ Reverse commuting and Black employment have been associated with public transit for more than 25 years. Note this reference from a 1967 Business Week article. "For Washington's [D.C.] big (63\%) Negro population, rapid transit offers the prospect of better access to jobs in the suburbs, where warehouses and plants have been fleeing in search of cheaper land." "Getting Washington to work on time," Business Week, September 30, 1967, 60.

${ }^{10} \mathrm{New}$ Jersey Transit operates transit service for the entire state of New Jersey. New York City includes New York City Metropolitan Transit Authority and the Long Island Railroad.

${ }^{11}$ Systems are in Atlanta, Baltimore, Chicago, Houston, Miami, Minneapolis, New Jersey, Philadelphia, San Francisco, and Washington. These systems represent approximately 21 percent of transit employment in 1984.

${ }^{12}$ Administrative Support includes those positions classified by some transit systems as Office Clerical. ${ }^{13}$ Metropolitan Council Transit Operations, Minneapolis, MN, reported two additional occupational categories, semi-skilled operative and unskilled laborers. Semi-skilled operatives were combined with the Skilled Craft category. Unskilled Laborers were combined with Service Workers.

${ }^{14}$ This information includes same systems as in Table 5 and represents 20 percent of transit employment in 1985.

${ }^{15}$ Administrative Support includes those positions classified by some transit systems as Office Clerical. ${ }^{16}$ Metropolitan Council Transit Operations, Minneapolis, MN, reported two additional occupational categories, semi-skilled operative and unskilled laborers. Semi-skilled operatives were combined with the Skilled Craft category. Unskilled Laborers were combined with Service Workers.

${ }^{17}$ Systems are those in Baltimore, Chicago, Houston, Miami, New Jersey, Philadelphia, Washington, San Francisco, and Long Island Railroad and New York City Transit. These systems represent approximately 46 percent of transit employment in 1989.

${ }^{18}$ Administrative Support includes those positions classified by some transit systems as Office Clerical. ${ }^{19}$ Metropolitan Council Transit Operations, Minneapolis, MN, reported two additional occupational categories, semi-skilled operative and unskilled laborers. Semi-skilled operatives were combined with the Skilled Craft category. Unskilled Laborers were combined with Service Workers.

${ }^{20}$ Systems are those in Atlanta, Baltimore, Chicago, Miami, Minneapolis, Philadelphia, Houston, San Francisco, Washington, and Long Island Railroad, and New York City Transit. These systems represent approximately 43 percent of transit employment in 1990.

${ }^{21}$ Administrative Support includes those positions classified by some transit systems as Office Clerical.

${ }^{22}$ Metropolitan Council Transit Operations, Minneapolis, MN, reported two additional occupational 
categories, semi-skilled operative and unskilled laborers. Semi-skilled operatives were combined with the Skilled Craft category. Unskilled Laborers were combined with Service Workers.

${ }^{23}$ Systems are those in Atlanta, Baltimore, Chicago, Houston, Miami, Minneapolis, New Jersey, Philadelphia, San Francisco, Washington, New York City Transit, and Long Island Railroad. These systems represent approximately 47 percent of transit employment in 1991.

${ }^{24}$ Administrative Support includes those positions classified by some transit systems as Office Clerical. ${ }^{25}$ Metropolitan Council Transit Operations, Minneapolis, MN, reported two additional occupational categories, semi-skilled operative and unskilled laborers. Semi-skilled operatives were combined with the Skilled Craft category. Unskilled Laborers were combined with Service Workers.

${ }^{26}$ These systems are the same as those shown in Table 6 and represent approximately 43 percent of transit employment in 1993.

${ }^{27}$ Administrative Support includes those positions classified by some transit systems as Office Clerical. ${ }^{28}$ Metropolitan Council Transit Operations, Minneapolis, MN, reported two additional occupational categories, semi-skilled operative and unskilled laborers. Semi-skilled operatives were combined with the Skilled Craft category. Unskilled Laborers were combined with Service Workers.

${ }^{29}$ Employees classified as officials/administrators and professionals provide the most accurate number of transit "management positions." The number of management positions under the remaining job classifications are unavailable and difficult to determine. For example, technicians may include professional engineers or data collectors. This is also the case for supervisors and managers in these classifications.

${ }^{30}$ Since the NFBPA members represent all areas of public service, only those members identified as transit officials were included in the selection process.

${ }^{31}$ Jeffress, 96.

${ }^{32}$ According to the Current Population Survey (CPS) definition, the workforce is comprises all noninstitutional civilians 16 years and over that: work for pay or profit or 15 hours or more during one week; and workers that are laid off for noneconomic reasons (illness, weather conditions, vacation, labor-management dispute, etc.).

${ }^{33}$ Bureau of Labor Statistics, http://stats.bls.gov/news.release/ecopro.toc.htm, "BLS Releases New 1994-2005 Employment Projections,” December 1, 1995.

${ }^{34}$ Manuel Padron, "Impacts of Changing Demographics on Transit Planning," presentation circa 1992, 1. ${ }^{35}$ Alan E. Pisarski, Travel Demands in the 1990s, report prepared for Office of Highway Information Management, HPM-40, page 10.

${ }^{36}$ David F. Schulz, "Can Transit Be Saved?," Chicago Tribune, July 1992.

${ }^{37}$ Padron, 1.

${ }^{38}$ Wade Lawson, "The Continuing Evolution of Public Transportation Policy," in Exploring New Frontiers: Proceedings of Symposium II on African-American Mobility Issues , January 1996.

${ }^{39}$ Data on employment discrimination claims with the EEOC for the transit industry was requested, but the information was not provided.

${ }^{40}$ Lex K. Larson, "Employment Discrimination, Eleventh Circuit: Hill v. MARTA," Duke University, March 1995, 841 F.2d.

${ }^{41}$ Reginald V. Speegle, "The Substantive Impact of Legislation on Employment Discrimination and the Civil Rights Act of 1991," National Black Law Journal V.13, Spring, 1993, 198.

${ }^{42}$ A Fact-Finding Report of the Federal Glass Ceiling Commission, Good For Business: Making Full Use of The Nation s Human Capital, (U.S. Department of Labor 1992) p. 3.

${ }^{43}$ Edward Weiner, Urban Transportation Planning in the United States: An Historical Overview, (Praeger, 1987), 92.

${ }^{44}$ Under the Intermodal Surface Transportation Efficiency Act of 1991, the UMTA became the Federal Transit Administration. 
Women in Transit

B. Ward and E. Hill

${ }^{45}$ Alcee Hastings, "Keynote Address," presented at Beyond the Horizon: Symposium III on African-American Mobility Issues, Tampa, FL, 1996.

${ }^{46}$ Weiner, 40.

${ }^{47}$ Office of the Secretary of Transportation, "Urban Transportation Planning in the United States: An Historical Overview," revised edition, prepared by Edward Weiner, November 1992, 239.

${ }^{48} \mathrm{Ibid}, 240$.

${ }^{49}$ Passenger Transport, "Mineta Urges Full Funding of ISTEA,” November 30, 1992, 2.

${ }^{50}$ Dr. Frank Enty, "Looking Ahead," The Cable Journal, Spring 1994, 22.

${ }^{51}$ Ibid.

${ }^{52}$ Anthony A. Saka, "Assessment of ITS Impact in the Urban Minority Community." Proceedings from the 1996 Annual ITS America Meeting. Page 1161.

${ }^{53}$ Federal Transit Administration, "Impact of Transit Funding Cuts," http://www.fta.dot.gov/fta/library/ money/fy96cut/BFFLOTP.HTM.

${ }^{54}$ Alcee Hastings, "Keynote Address," presented at Beyond the Horizon: Symposium III on AfricanAmerican Mobility Issues, Tampa, Fl., 1996.

${ }^{55}$ Hamlin \& Associates, "The Impact of Corporate Restructuring and Downsizing on the Managerial Careers of Minorities and Women: Lessons Learned from Nine Corporations," Executive Summary, September 1994, 3.

${ }^{56} \mathrm{P}=$ Professional and $\mathrm{A}=$ Administration 